\title{
Estimation of hydrophobicity of segments in Amyloid $\beta 42$ partly comprising D-amino acids
}

\author{
Toratane Munegumi* \\ Department of Science Education, Naruto University of Education, 748 Nakashima, Takashima, \\ Naruto-Cho, Naruto, Tokushima 772-8502, Japan.
}

\begin{abstract}
Terrestrial D-amino acids have been found as either free amino acids or the components of peptides and proteins. The proteins originally comprising L-amino acids sometimes change into the D-amino acid-comprising form following natural epimerization. The resulting peptides and proteins have different physical, chemical, and/or biological properties from the original forms. Looking at the oligopeptide region of proteins, the hydrophobicity of oligopeptides has been calculated using semiempirical methods. The oligopeptides partly comprising D-amino acids mostly have more hydrophobic regions than the oligopeptides comprising only L-amino acids. This research focuses on the epimerization and isomerization of aspartic acid residues of the segments in the wild type and Italian mutant of Amyloid $\beta 42$ to estimate the relationship between the epimerization and the hydrophobicity change. Higher hydrophobicity is known to facilitate the aggregation and toxicity of Amyloid $\beta 42$ and its mutants. This research used a linear relationship between experimental $\log P$ and calculated $\log P$ $(C \log P)$ in which $\log P$ is the logarithm of the partition coefficient $P$ in 1-octanol to water. The calculation using semiempirical methods (PM5) validated the relationship between the structure change and the hydrophobicity during the epimerization of the oligopeptides. The epimerization at the two common aspartic residues, $\mathrm{D}^{1}$ and $\mathrm{D}^{7}$
\end{abstract}

\footnotetext{
*Email id: tmunegumi@naruto-u.ac.jp
}

for the wild type and the Italian mutant, gave smaller Clog $P$ values than non-epimerized ones. The epimerization at another common residue $\mathrm{D}^{23}$ showed larger Clog $P$ for the hexapeptide segments. Clog $P$ values of the epimerized hexapeptide segments of the Italian mutant were larger than those of the wild type. The results suggest that the original and D-epimer at $\mathrm{D}^{23}$ of the Italian mutant must be more hydrophobic than those of the wild type. The estimation agrees with the experimental results of aggregation.

KEYWORDS: amino acids, oligopeptide, heterochiral, homochiral, partition coefficient, epimerization.

\section{INTRODUCTION}

Sequences comprising D-amino acid residues [1-4] have been found in peptide antibiotics [2-4], peptide glycan [2-4], bioactive peptides [4-14], and human tissues [3, 14-24]. Proteins are originally made from L-amino acids coded on deoxyribonucleic acid. Some types of L-amino acid residues in such proteins can sometimes become D-amino acid residues by epimerization $[16,20,25,26]$, which is a type of isomerization reaction to yield diastereomers. The emergence of D-aspartic acid residues by epimerization has been found in proteins [1-4] such as myelin [7], myelin basic proteins [7], Amyloid $\beta$ [17], aging of human lens $\alpha \mathrm{A}$-crystallin [19-21], and others [1-4]. Aspartic acid racemizes as the free form [27] and epimerizes as amino acid residues in the 
peptide form [28] with the fastest rate constants of all the amino acids. Aspartic acid has an inductive side chain, a methyl carboxy group, which also can remove $\alpha$-hydrogen from aspartic acid or its residue [27] through an achiral intermediate to racemize or epimerize. However, $\beta$-DL-aspartyl residues have been detected in $\alpha \mathrm{A}$-crystallin [20, 29]. From the results, imide intermediates were suggested [29-32] as shown in Figure 1.

Each L-aspartic acid residue in peptides and proteins generally has a side-chain group, methyl carboxy that can intramolecularly dehydrate and cyclize to an L-imide. The resulting L-imide structure can give an L-aspartic acid residue (L-Asp), an L- $\beta$-aspartic residue (L- $\beta$ Asp), or an achiral cyclic structure, which can isomerize to D-imide. These reaction paths are categorized as a type of epimerization in peptides and proteins. D-imide can react again to lead to a D-aspartic acid residue (D-Asp), a D- $\beta$-aspartic residue (D- $\beta$ Asp), or reverse to the achiral cyclic structure. After the set of reactions, six types of isomers may be found as shown in Figure 1.
These epimerized proteins resulting in D-amino acid residues may be able to make the conformation of the proteins more hydrophobic. Previous studies $[25,26]$ have demonstrated that the emergence of D-amino acid residues in oligopeptides and proteins will usually lead to a segmental decrease in water solubility of the corresponding area. The water solubility of a compound increases with increasing hydrophilicity and decreases with increasing hydrophobicity. Several research results [33-38] have shown the differences in the hydrophobicity between the oligopeptides (homochiral peptide diastereomers) composed of only L-amino acids and the oligopeptides (heterochiral peptide diastereomers) comprising D-amino acids.

The previous reports $[25,26]$ have clarified that most of the oligopeptides partly comprising Damino acid residues are usually more hydrophobic than the oligopeptides composed of all L-amino acid residues. Reverse-phase high-performance liquid chromatography (RP-HPLC) has been used for the separation of oligopeptide diastereomers to demonstrate that many heterochiral peptide

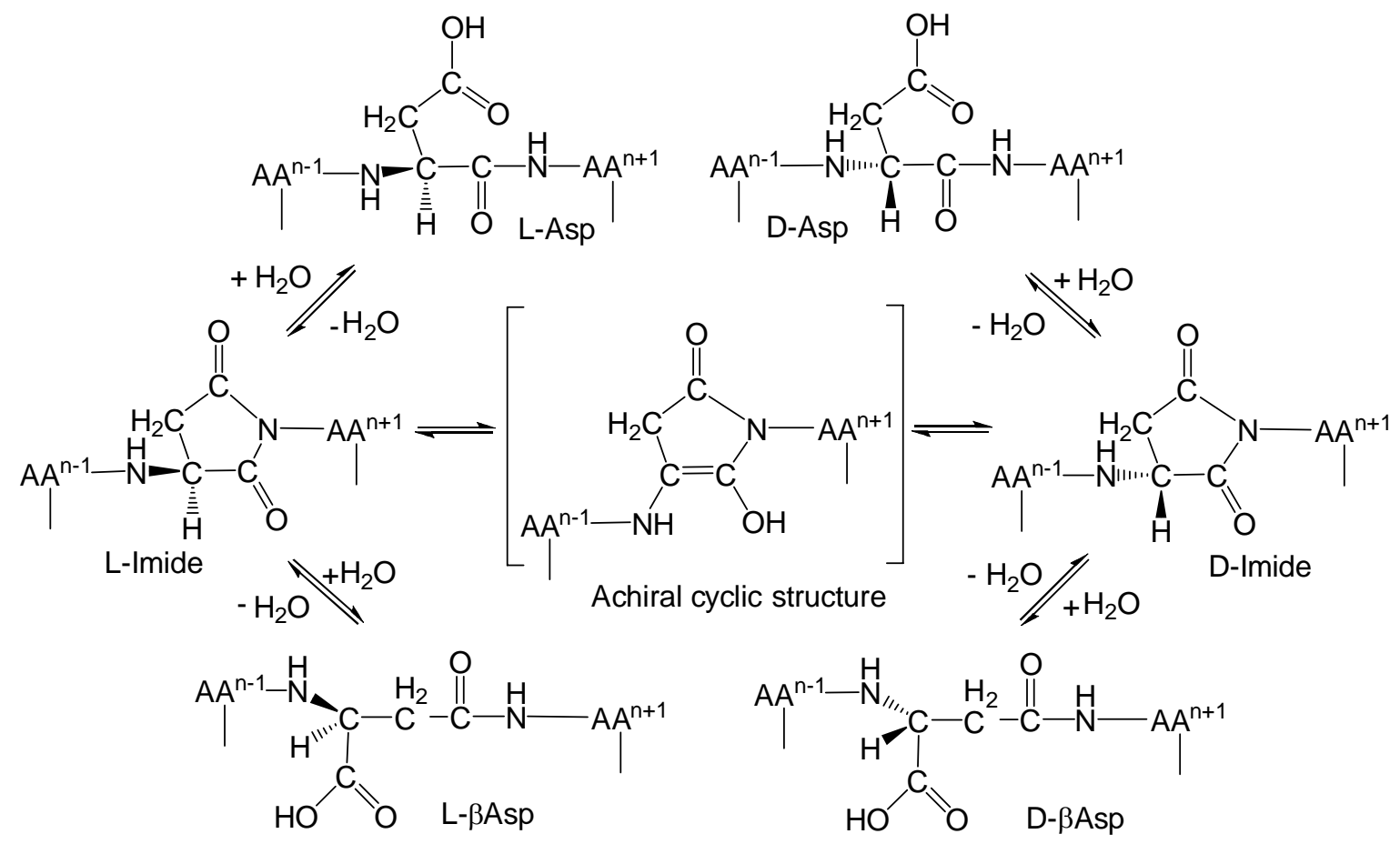

Figure 1. Epimerization mechanism facilitated by the imide structure formation from aspartyl residue $\left(\mathrm{AA}^{\mathrm{n}}\right)$ in peptides. $\mathrm{AA}^{\mathrm{n}-1}$ and $\mathrm{AA}^{\mathrm{n}+1}$ are the $N$-terminal side and $C$-terminal side residues of the $\mathrm{AA}^{\mathrm{n}}$ residue. 
diastereomers are eluted later than their homochiral peptide diastereomers on RP-HPLC. Analyses on RP-HPLC can be used to determine the coefficients $a, b$ in Eqn. 1 . The capacity factor $k^{\prime}$ is the ratio of the retention time difference $\left(t_{\mathrm{R}}-\right.$ $\left.t_{0}\right)$ to the retention time $\left(t_{0}\right)$ of a nonretarded compound in RP-HPLC: $k^{\prime}=\left(t_{\mathrm{R}}-t_{0}\right) / t_{0}$. The $\log P$ [39-48] values, namely, the logarithm of an experimental partition coefficient $P$ for 1-octanol in water to be an indicator of hydrophobicity, can be used for a hydrophobicity scale of peptides. There is a relationship between the $\log P$ value and the capacity factor $\left(k^{\prime}\right)$ on RP-HPLC as shown in Eqn. 1 [48, 49].

$$
\log P=a \log k^{\prime}+b
$$

The $\log P$ values have been calculated with a semiempirical method using a computer program for evaluating the hydrophobicity. The $\log P$ values (Clog P) [46, 50] calculated by a semiempirical method using a computer program can evaluate the hydrophobicity change of peptides in the epimerized amino acid residues in many peptides and proteins $[25,26]$.

Amyloid $\beta 40$ and $\beta 42$ are known to be the main components of amyloid fibrils, which are suggested to have neurotoxicity related to Alzheimer's disease [51, 52]. Several types of mutants of the amyloids shown in Figure 2 have been found [51].
The wild types of Amyloid $\beta 40$ and $\beta 42$ have common sequences from the $N$-terminal to the $40^{\text {th }}$ amino acid residue from the $N$-terminus. The amino acid residues of $\mathrm{AA}^{21}, \mathrm{AA}^{22}$, and $\mathrm{AA}^{23}$ are Ala (A), Glu (E), and Asp (D), respectively. The $C$-terminal residue, $\mathrm{AA}^{41}-\mathrm{AA}^{42}\left(\mathrm{I}^{41} \mathrm{~A}^{42}\right)$, contributes to producing the higher aggregation rate of Amyloid $\beta 42$ than Amyloid $\beta 40$ [51, 53]. The fastest aggregation rate was detected in an experiment using the Italian mutant comprising $\mathrm{A}^{21}, \mathrm{~K}^{22}$, and $\mathrm{D}^{23}$. The Italian mutant is suggested as the most hydrophobic of the peptides shown in Figure 2.

The reason for the highest aggregation rate of the Italian mutant was explained by the highest hydrophobicity derived from the stability of the $\beta$-sheet structure [51]. Basically, Amyloid $\beta 42$ has two turn structures in two different places: (1) $\mathrm{E}^{22}$ $D^{23}$ and (2) $G^{38}-G^{39}$. The back-and-forth character of each turn structure induces each $\beta$-sheet pairing to be more hydrophobic and aggregate between different Amyloid $\beta 42$ molecules [51, 53]. The $\beta$-sheet pairing in the back-and-forth changes of $\mathrm{G}^{38}-\mathrm{G}^{39}$ can be induced by the conformation change of $\mathrm{I}^{41}$ along with changing the trans peptide bond to cis $[51,53]$. However, the feature of the $\beta$-sheet pairing involving the $\mathrm{AA}^{22}-\mathrm{AA}^{23}$ turn structure of mutants may depend on the sequences in $\mathrm{AA}^{22}-\mathrm{AA}^{23}$. The Italian mutant is the

\begin{tabular}{|c|c|c|c|}
\hline $\begin{array}{c}\text { Amyloid } \beta 40 \text { and } \beta 42 \\
\text { mutation type }\end{array}$ & $\mathrm{AA}^{21}$ & $\mathrm{AA}^{22}$ & $\mathrm{AA}^{23}$ \\
\hline Wild & $\mathrm{A}$ & $\mathrm{E}$ & $\mathrm{D}$ \\
\hline Flemish & $\mathrm{G}$ & $\mathrm{E}$ & $\mathrm{D}$ \\
\hline Arctic & $\mathrm{A}$ & $\mathrm{G}$ & $\mathrm{D}$ \\
\hline Dutch & $\mathrm{A}$ & $\mathrm{Q}$ & $\mathrm{D}$ \\
\hline Italian & $\mathrm{A}$ & $\mathrm{K}$ & $\mathrm{D}$ \\
\hline lowa & $\mathrm{A}$ & $\mathrm{E}$ & $\mathrm{N}$ \\
\hline
\end{tabular}

Figure 2. Peptide sequences of the wild and mutant types of Amyloid $\beta 40$ and $\beta 42$. 
most hydrophobic in the amyloids including mutants and the wild type. The reason has been explained by the ion bonding between the sidechain ammonium cation of $\mathrm{K}^{22}$ and the side-chain carboxy anion of $\mathrm{D}^{23}$ [51].

The epimerization in aspartic residues $\mathrm{D}^{1}, \mathrm{D}^{7}$, and $\mathrm{D}^{23}$ as a different factor has been dealt with for the increase in the hydrophobicity of Amyloids $\beta 40$ and $\beta 42$ [52-57]. Tryptic digestions [52] of the wild type of Amyloid $\beta 42$ revealed epimerization at $D^{1}$ and $D^{7}$ but not at $D^{23}$. The epimerization was explained by the reaction mechanism through imide formation at the aspartic residues. The L-imide structure can more easily release a proton than usual L-aspartic residues to give an achiral cyclic structure, which can change to D-imide and then D-aspartic residues in the epimerization mechanism shown in Figure 2. The lack of isomerization and epimerization at $\mathrm{D}^{23}$ was explained by limiting imide formation with $\mathrm{V}^{24}$ because of its bulky hydrophobic side chain. These results of epimerization at D (Asp) residues have not been discussed as depending on the hydrophobicity change of Amyloid $\beta$.

Other researchers treated the synthesized Amyloid $\beta 42$ analogues comprising D-aspartic residues to compare their hydrophobicity [54-56]. Fibril formation was enhanced using Amyloid $\beta 42$ analogues modified with D-Asp at $\mathrm{D}^{7}$ or $\mathrm{D}^{23}$ but not $\mathrm{D}^{1}$ of the wild type [54]. Research [57] using other analogues that switched $D^{23}$ to the isomers -L-isoAsp (L- $\beta A s p), ~ D-A s p$, and D-isoAsp (D$\beta A s p)$ - reported that L- $\beta$ Asp and D-Asp showed a similar aggregative ability to the wild type and D- $\beta$ Asp showed weak aggregative ability. Further, simultaneously switching both $\mathrm{D}^{7}$ and $\mathrm{D}^{23}$ to D-Asp [55] enhanced oligomerization, fibril formation, and neurotoxic effect compared with the wild type but switching $\mathrm{D}^{1}, \mathrm{D}^{7}$, and $\mathrm{D}^{23}$ to D-Asp suppressed malignant effects.

Although there are only three Asp residues in Amyloid $\beta 42$, double or triple epimerization forms many types of analogues. The relationship between epimerization and aggregation may need many types of peptide syntheses. However, a calculation without synthesis can simulate many types of analogues. This paper reports the differences between the segmental sequences in Amyloid $\beta 42$ composed of L-amino acids and the same sequences comprising a D-Asp residue in Clog $P$ values. The research focuses on the epimerization at the common residues $\left(D^{1}, D^{7}\right.$ and $D^{23}$ ) between the wild type and Italian mutant of Amyloid $\beta 42$ to compare the values of $C \log P$ as a convenient factor for measuring hydrophobicity.

\section{MATERIALS AND METHODS}

The mechanically optimum structures of the diastereomeric peptides were determined by calculation using molecular mechanics (MM3) from the SCIGRESS program from Fujitsu, Tokyo, Japan. Subsequently, a semiempirical calculation for the resulting optimum structure was carried out using Molecular Orbital Package (MOPAC) based on the PM5 Hamiltonian [41] to give the heat of formation in vacuum and in water. The energy unit used was $\mathrm{kcal} / \mathrm{mol}(1 \mathrm{~kJ} / \mathrm{mol}=4.18$ $\mathrm{kcal} / \mathrm{mol}$ ). The solvent-accessible surface area for the stable structures was calculated and expressed in square Ångstrom $\left(1.0 \AA^{2}=0.01 \mathrm{~nm}^{2}\right)$. The Clog $P$ value for the peptide structures was sequentially calculated on a spreadsheet, an attachment program to SCIGRESS.

For estimating actual $\log P$ values, the relationship between $C \log P$ and experimental $\log$ $P$ (Exptl. $\log \mathrm{P}$ ) values of amino acids and oligopeptides was evaluated. Exptl. $\log P$ values have been correlated to their $\log k^{\prime}$ values reported in the literature [26]. The present research corrected the correlation using the previously reported $\log P$ values $[39,40]$ of amino acids and peptides and $\log k^{\prime}$. A semiempirical program based on MOPAC with the PM5 Hamiltonian was used for the calculation. $C \log P$ values using the PM5 method can be determined from the formula shown in Eqn. 2.

$$
\begin{aligned}
& \mathrm{C} \log P=-0.0305(\mathrm{~A})+0.0215(\mathrm{~B})+0.0266 \text { (C) } \\
& -1.2673 \text { sqrt (D) }-3.5427 \text { sqrt (E) }+1.8021
\end{aligned}
$$

This equation was obtained by a comparison of Exptl. $\log P$ for many types of amino acids and $N$-acetyl peptide amides [46] with those of Clog $P$ values. The factors for the five functions (A to E) were estimated and optimized to produce the most efficient linear correlation between Exptl. $\log P$ and $C \log P$ values. In this equation, $C \log P$ is composed of several functions as follows: A: heat of formation $(\mathrm{kcal} / \mathrm{mol})$ at the PM5 geometry, B: solvent-accessible surface area (square Ångstroms), 
C: the heat of formation in water at the PM5 geometry, D: number of nitrogen atoms in the molecule, $\mathrm{E}$ : number of oxygen atoms in the molecule.

\section{RESULTS AND DISCUSSION}

\section{Estimation of experimental $\log P$ values by calculated $\log P$}

Exptl. $\log P$ and $C \log P$ values of amino acids and $N$-acetyl peptide amides (Ac-peptide amides) are listed in Table 1.

A linear correlation has been reported $[25,26]$ between Exptl. $\log P$ and $C \log P$ of amino acids. Ac-peptide amides were used for the model compounds estimating $\log P$ values of peptide sequences of Amyloid $\beta 42$. These two types of compounds are useful for estimating $\log P$ values in the $\log P$ range between about -5 and 1 . The data in Table 1 are plotted in Figure 3, which reveals a good linear relationship $\left(R^{2}=0.978\right)$ between Exptl. $\log P$ and $\operatorname{Clog} P$ values. The relationship can be used for predicting the actual Exptl. $\log P$ values of the restricted Amyloid $\beta 42$ sequences from Clog $P$ values.

\section{Estimation of $\log P$ values of segmental Amyloid $\beta 42$ including $D^{1}$}

The Clog $P$ of the segment sequence $\mathrm{D}^{1} \mathrm{~A}^{2} \mathrm{E}^{3} \mathrm{~F}^{4}$ was calculated as Asp-Ala-Glu-Phe- $\mathrm{NH}_{2}$, which has a $C$-terminal amide structure. Calculated values of $\operatorname{Clog} P$ for the segmental Amyloid $\beta 42$ including $\mathrm{D}^{1}$ are shown in Table 2 and Figure 4. Clog $P$ values were in the range -3.51 to -1.39 . Smaller Clog $P$ values of epimers were obtained in most D-epimers more than L-epimers except for D19 and D110. For example, the Clog $P$ value for D12 (D-form, -2.32) was smaller than for D11 (L-form, -1.92). The epimerization in $\mathrm{D}^{1}$ will produce more hydrophilic structures.

\section{Estimation of $\log P$ values of segmental Amyloid $\beta 42$ including $D^{7}$}

The Clog $P$ of the segment sequence $H^{6} D^{7} S^{8} G^{9} Y^{10}$ was calculated as Ac-His-Asp-Ser-Gly-Tyr- $\mathrm{NH}_{2}$, which has a $C$-terminal amide structure. Calculated values of $C \log P$ for segmental Amyloid $\beta 42$ including $\mathrm{D}^{7}$ are shown in Table 3 and Figure 5. Smaller Clog $P$ values were obtained in all
D-epimers more than L-epimers. The epimerization at $\mathrm{D}^{7}$ will form more hydrophilic structures. The peptide structures including Histidine residues are according to the structures in basic solutions $(\mathrm{pH}$ 8 to 9), in which the side chain of Tyr almost does not ionize. The peptide structures including the HisH sequence are neutral or acidic $(\mathrm{pH}<7)$. The peptide structures including both $\mathrm{HisH}$ and $\mathrm{AspH}$ (or $\beta$ AspH) are according to acidic conditions ( $\mathrm{pH}$ $<2$ ). Therefore, at $\mathrm{pH}$ lower than 9, the peptide sequences having the $\mathrm{D}$-form at $\mathrm{D}^{7}$ are more hydrophilic than those of the original sequences having the L-form. The hydrophilicity of segment peptides isomerized at $\mathrm{D}^{1}$ means lower aggregation, which fits with the results having actual lower aggregation features. As shown above [52-57], Amyloid $\beta 42$ in which both $\mathrm{D}^{7}$ and $\mathrm{D}^{23}$ were exchanged to D-Asp enhanced fibril formation. Therefore, the epimerization at $\mathrm{D}^{23}$ may contribute to more hydrophobicity of Amyloid $\beta 42$ even though the epimerization at $D^{7}$ makes hydrophilicity.

\section{Estimation of $\log P$ values of segmental Amyloid $\beta 42$ including $D^{23}$}

\subsection{Chemical structures of segmental Amyloid $\beta 42$ including $D^{23}$}

As shown in Figure 2, there are several mutants of Amyloid $\beta 42$. The Italian mutant is the most hydrophobic and the most easily aggregated among them. The following sections compare Clog $P$ of the wild type of segment peptides and epimerized peptides with those of the Italian mutant. Figure 6 shows the chemical structures of the bending segmental areas $\left(\mathrm{AA}^{21}-\mathrm{AA}^{22}-\mathrm{AA}^{23}\right.$ $\left.\mathrm{AA}^{24}\right)$ of the wild type $\left(\mathrm{A}^{21}-\mathrm{E}^{22}-\mathrm{D}^{23}-\mathrm{V}^{24}\right)$ and the Italian mutant $\left(\mathrm{A}^{21}-\mathrm{K}^{22}-\mathrm{D}^{23}-\mathrm{V}^{24}\right)$ of Amyloid $\beta 42$. The bending segmental area of peptides can be classified into three types of segments: $\alpha$ peptides, imides, and $\beta$-peptides. Each type of segment has two features, namely L-Asp or D-Asp at $\mathrm{D}^{23}$ and trans 1 or trans 2. Because of the interactions between the two side chains of $\mathrm{AA}^{22}$ and $\mathrm{AA}^{23}$, the bending at this sequence site may be more stable. There may be a substantial barrier against the conformation change between trans 1 and trans 2 . This research presumes that both trans 1 and trans 2 are not tautomerized but stabilized. The interactions between the side chains of $\mathrm{AA}^{22}$ 
Table 1. Calculated $\log P$ values of amino acids and $N$-acetyl-peptide amides.

\begin{tabular}{|c|c|c|c|c|c|c|c|}
\hline $\begin{array}{c}\text { Amino acids and } \\
N \text {-Acetyl-Peptide } \\
\text { amides }\end{array}$ & $\begin{array}{l}\text { A: Hf in } \\
\text { vacuum } \\
\text { (kcal/mol) }\end{array}$ & $\begin{array}{l}\text { B: Solvent } \\
\text { accessible } \\
\text { area }\left(\AA^{2}\right)\end{array}$ & $\begin{array}{c}\mathrm{C}: \mathrm{Hf} \text { in } \\
\mathrm{H}_{2} \mathrm{O} \\
\text { (kcal/mol) }\end{array}$ & $\begin{array}{c}\text { D: } \\
\text { Number } \\
\text { of } N \text { atom }\end{array}$ & $\begin{array}{c}\text { E: } \\
\text { Number of } \\
\text { O atom }\end{array}$ & $\mathrm{Clog} P$ & $\begin{array}{c}\text { Exptl. } \\
\log P\end{array}$ \\
\hline Glycine (Gly) & -80.70 & 105.5 & -133.1 & 1 & 2 & -3.30 & -3.21 \\
\hline Alanine (Ala) & -88.10 & 123.5 & -138.4 & 1 & 2 & -2.82 & -2.85 \\
\hline Valine (Val) & -99.50 & 152.9 & -144.9 & 1 & 2 & -2.02 & -2.26 \\
\hline Leucine (Leu) & -106.7 & 175.1 & -153.1 & 1 & 2 & -1.54 & -1.74 \\
\hline Isoleucine (Ile) & -104.1 & 172.7 & -148.3 & 1 & 2 & -1.54 & -1.76 \\
\hline Serine (Ser) & -133.0 & 133.3 & -179.2 & 1 & 3 & -3.46 & -3.33 \\
\hline Threonine (Thr) & -140.7 & 149.3 & -183.0 & 1 & 3 & -2.98 & -2.98 \\
\hline Phenylalanine (Phe) & -68.40 & 197.6 & -114.8 & 1 & 2 & -1.21 & -1.52 \\
\hline Tyrosine (Tyr) & -112.3 & 207.8 & -162.9 & 1 & 3 & -2.06 & -2.66 \\
\hline Tryptophane (Trp) & -47.10 & 226.2 & -95.0 & 2 & 2 & -1.24 & -1.06 \\
\hline Proline (Pro) & -86.30 & 146.8 & -130.6 & 1 & 2 & -2.17 & -2.54 \\
\hline Methionine (Met) & -89.60 & 184.9 & -139.5 & 1 & 2 & -1.49 & -2.00 \\
\hline Glutamine (Gln) & -147.1 & 178.8 & -199.2 & 2 & 3 & -3.11 & -3.15 \\
\hline Asparagine (Arg) & -142.1 & 157.9 & -189.5 & 2 & 3 & -3.45 & -3.82 \\
\hline Glutamic acid (GluH) & -183.4 & 175.0 & -238.2 & 1 & 4 & -3.55 & -3.66 \\
\hline Glutamic acid ${ }^{-}\left(\mathrm{Glu}^{-}\right)$ & -263.3 & 170.6 & -348.9 & 1 & 4 & -4.15 & -3.66 \\
\hline Aspartic acid (AspH) & -183.1 & 154.6 & -229.6 & 1 & 4 & -3.77 & -3.68 \\
\hline Aspartic acid (Aspº) $^{-}$ & -254.4 & 151.4 & -344.5 & 1 & 4 & -4.72 & -3.68 \\
\hline Arginine $^{+}$ & 39.0 & 222.0 & -45.7 & 4 & 2 & -3.39 & -4.20 \\
\hline LysineH $^{+}$ & 41.2 & 198.0 & -36.5 & 2 & 2 & -2.98 & -3.05 \\
\hline His & -56.6 & 182.0 & -106.9 & 3 & 2 & -2.62 & -2.52 \\
\hline Ac-Tyr-Phe- $\mathrm{NH}_{2}$ & -152.6 & 375.8 & -183.9 & 3 & 4 & 0.35 & 0.54 \\
\hline Ac-Thr-Val-NH ${ }_{2}$ & -217.0 & 289.1 & -242.8 & 3 & 4 & -1.12 & -1.25 \\
\hline Ac-Ala-Leu- $\mathrm{NH}_{2}$ & -174.6 & 279.8 & -197.9 & 3 & 3 & -0.47 & -0.54 \\
\hline Ac-Trp-Val-NH ${ }_{2}$ & -121.6 & 363.4 & -149.7 & 4 & 3 & 0.65 & 0.73 \\
\hline Ac-Ser-Val-NH ${ }_{2}$ & -207.9 & 277.4 & -235.0 & 3 & 4 & -1.44 & -1.53 \\
\hline Ac-Val-Gly-NH & -160.5 & 246.8 & -185.2 & 3 & 3 & -1.27 & 0.45 \\
\hline Ac-Trp-Gly-Phe-NH ${ }_{2}$ & -130.3 & 439.4 & -166.3 & 5 & 4 & 0.86 & 0.99 \\
\hline Ac-Leu-Thr-Leu-NH ${ }_{2}$ & -288.1 & 414.3 & -317.9 & 4 & 5 & 0.56 & 0.24 \\
\hline Ac-Leu-Ser-Phe- $\mathrm{NH}_{2}$ & -239.0 & 418.6 & -270.5 & 4 & 5 & 0.42 & 0.23 \\
\hline Ac-Ala-Tyr-Leu- $\mathrm{NH}_{2}$ & -241.2 & 409.8 & -274.8 & 4 & 5 & 0.18 & -0.04 \\
\hline
\end{tabular}

Hf: Heat of formation; Clog P: Calculated log P; Exptl. Log P: Experimental log P.

Glutamic acid ${ }^{-}\left(\mathrm{Glu}^{-}\right)$and Aspartic $\operatorname{acid}^{-}\left(\mathrm{Asp}^{-}\right)$: side chains are carboxylate.

Glutamic acid (GluH) and Aspartic acid (AspH): side chains are protonated; Ac: Acetyl-. 


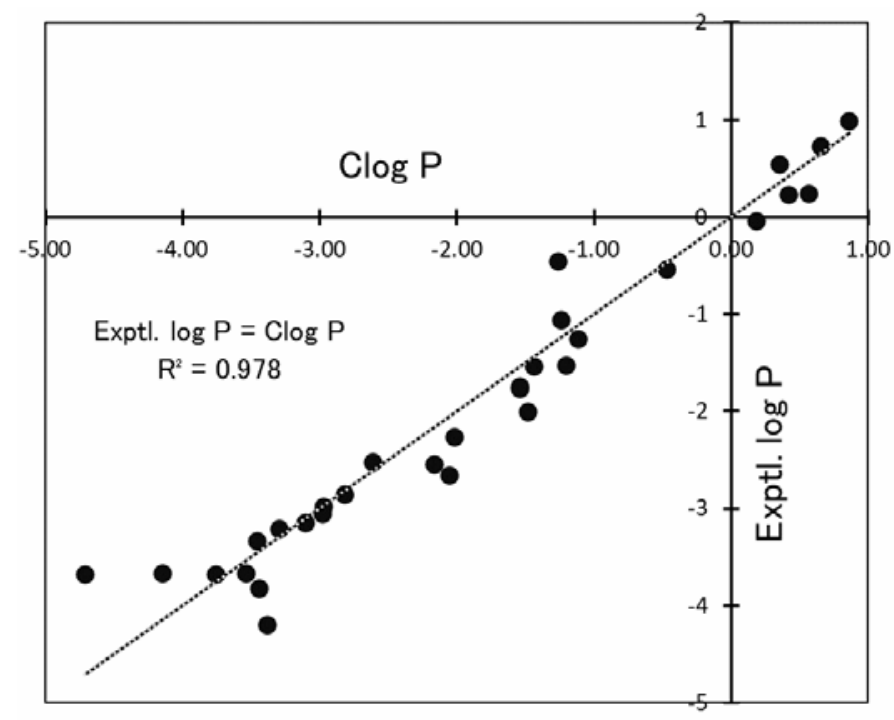

Figure 3. The linear relationship between Experimental $\log P$ and $C \log P$. Clog $P$ values were calculated by inserting values of $\mathbf{A}: \Delta H_{\mathrm{f}}$ in vacuum (kcal $\left./ \mathrm{mol}\right)$; B: Solvent accessible area $\left(\AA^{2}\right)$; $\mathbf{C}: \Delta H_{\mathrm{f}}$ in $\mathrm{H}_{2} \mathrm{O}(\mathrm{kcal} / \mathrm{mol})$; D: Number of $\mathrm{N}$ atoms; and $\mathbf{E}$ : Number of $\mathrm{O}$ atoms into the equation: $\operatorname{Clog} P=-0.0305(\mathrm{~A})+0.0215(\mathrm{~B})+0.0266(\mathrm{C})-1.2673$ sqrt $(\mathrm{D})-3.5427$ sqrt $(\mathrm{E})+1.8021$.

Table 2. Calculated $\log P$ values of sequences from $\mathrm{D}^{1}$ to $\mathrm{F}^{4}$ in Amyloid $\beta 42$ including those isomerized at $\mathrm{D}^{1}$.

\begin{tabular}{|c|c|c|c|c|c|c|c|}
\hline No. & Peptide amides & $\begin{array}{c}\text { A: } \\
\text { Hf in } \\
\text { vacuum } \\
\text { (kcal/mol) }\end{array}$ & $\begin{array}{c}\text { B: } \\
\text { Solvent } \\
\text { accessible } \\
\text { area }\left(\AA^{2}\right)\end{array}$ & $\begin{array}{c}\mathrm{C}: \\
\mathrm{Hf} \text { in } \\
\mathrm{H}_{2} \mathrm{O} \\
\text { (kcal/mol) }\end{array}$ & $\begin{array}{c}\text { D: } \\
\text { Number } \\
\text { of } N \\
\text { atom }\end{array}$ & $\begin{array}{c}\text { E: } \\
\text { Number } \\
\text { of } O \\
\text { atom }\end{array}$ & $C \log P$ \\
\hline D11 & Asp-Ala-Glu-Phe- $\mathrm{NH}_{2}$ & -438.9 & 450.9 & -524.4 & 5 & 8 & -1.92 \\
\hline D12 & D-Asp-Ala-Glu-Phe- $\mathrm{NH}_{2}$ & -440.7 & 437.6 & -530.7 & 5 & 8 & -2.32 \\
\hline D13 & AspH-Ala-GluH-Phe- $\mathrm{NH}_{2}$ & -216.1 & 486.5 & -319.0 & 5 & 8 & -2.49 \\
\hline D14 & D-AspH-Ala-GluH-Phe- $\mathrm{NH}_{2}$ & -222.1 & 465.2 & -317.3 & 5 & 8 & -2.72 \\
\hline D15 & Aspimide-Ala-Glu-Phe- $\mathrm{NH}_{2}$ & -309.3 & 424.6 & -358.7 & 5 & 7 & -1.39 \\
\hline D16 & D-Aspimide-Ala-Glu-Phe- $\mathrm{NH}_{2}$ & -312.4 & 410.3 & -359.5 & 5 & 7 & -1.59 \\
\hline D17 & Aspimide-Ala-GluH-Phe- $\mathrm{NH}_{2}$ & -152.3 & 463.6 & -259.2 & 5 & 7 & -2.69 \\
\hline D18 & D-Aspimide-Ala-GluH-Phe- $\mathrm{NH}_{2}$ & -160.5 & 404.2 & -251.7 & 5 & 7 & -3.51 \\
\hline D19 & $\beta$ Asp-Ala-Glu-Phe- $\mathrm{NH}_{2}$ & -444.8 & 428.0 & -535.4 & 5 & 8 & -2.53 \\
\hline D110 & D- $\beta$ Asp-Ala-Glu-Phe- $\mathrm{NH}_{2}$ & -445.9 & 435.3 & -539.8 & 5 & 8 & -2.45 \\
\hline D111 & $\beta$ AspH-Ala-GluH-Phe- $\mathrm{NH}_{2}$ & -222.8 & 456.6 & -310.8 & 5 & 8 & -2.71 \\
\hline D112 & D- $\beta$ AspH-Ala-GluH-Phe- $\mathrm{NH}_{2}$ & -227.5 & 450.5 & -312.9 & 5 & 8 & -2.75 \\
\hline
\end{tabular}

Hf: Heat of formation; Clog P: Calculated log P.

Glutamic acid (Glu) and Aspartic acid (Asp): side chains are carboxylate.

Glutamic acid (GluH) and Aspartic acid (AspH): side chains are protonated.

All the amino acids without heading D- have L-chirality.; Aspimide has an imide structure.

Heading only $\beta$ is $\beta$-carboxy of L-Asp making peptide bond with Ala residue.

Heading $D-\beta$ is $\beta$-carboxy of $D$-Asp making peptide bond with Ala residue. 


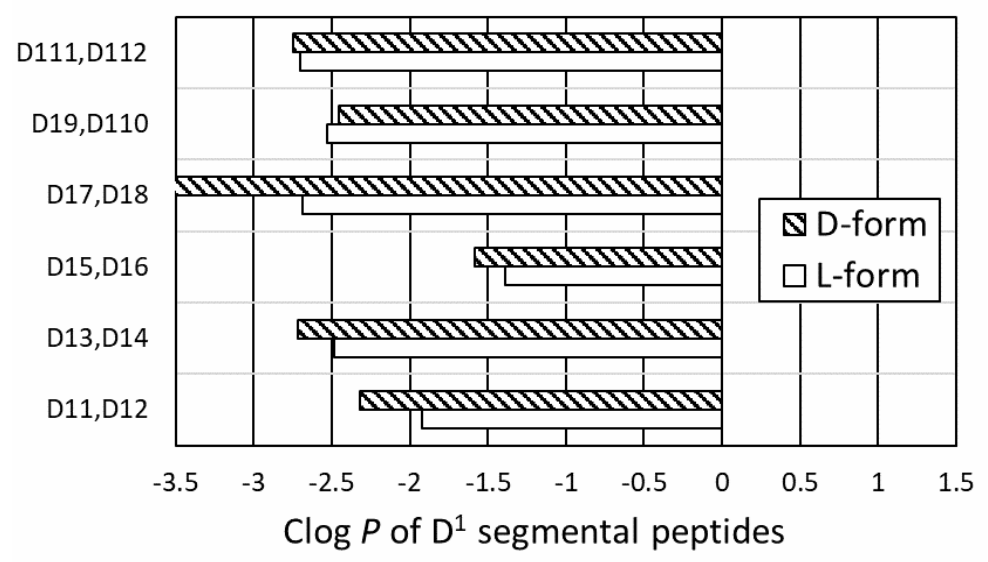

Figure 4. Comparison of Clog $P$ values between the L-epimer and D-epimer of the sequences including isomerized Asp residues from $\mathrm{D}^{1}$ to $\mathrm{F}^{4}$ in Amyloid $\beta 42$.

Table 3. Calculated $\log P$ values of sequences $H^{6} D^{7} S^{8} G^{9} Y^{10}$ in Amyloid $\beta 42$ including those isomerized at $\mathrm{D}^{7}$.

\begin{tabular}{|c|c|c|c|c|c|c|c|}
\hline No. & $N$-Acetyl-Peptide amides & $\begin{array}{c}\text { A: } \\
\text { Hf in } \\
\text { vacuum } \\
\text { (kcal/mol) }\end{array}$ & $\begin{array}{c}\text { B: } \\
\text { Solvent } \\
\text { accessible } \\
\text { area }\left(\AA^{2}\right)\end{array}$ & $\begin{array}{c}\mathrm{C}: \\
\mathrm{Hf} \text { in } \\
\mathrm{H}_{2} \mathrm{O} \\
\text { (kcal/mol) }\end{array}$ & $\begin{array}{c}\text { D: } \\
\text { Number } \\
\text { of } N \\
\text { atom }\end{array}$ & $\begin{array}{c}\text { E: } \\
\text { Number } \\
\text { of } O \\
\text { atom }\end{array}$ & $\mathbf{C l o g} \mathbf{P}$ \\
\hline D71 & Ac-His-Asp-Ser-Gly-Tyr-NH ${ }_{2}$ & -480.9 & 549.7 & -572.4 & 8 & 10 & -1.73 \\
\hline D72 & Ac-His-D-Asp-Ser-Gly-Tyr- $\mathrm{NH}_{2}$ & -479.7 & 555.8 & -585.9 & 8 & 10 & -1.99 \\
\hline D73 & Ac-HisH-Asp-Ser-Gly-Tyr- $\mathrm{NH}_{2}$ & -410.6 & 567.7 & -477.6 & 8 & 10 & -0.96 \\
\hline D74 & Ac-HisH-D-Asp-Ser-Gly-Tyr- $\mathrm{NH}_{2}$ & -407.1 & 539.1 & -481.4 & 8 & 10 & -1.78 \\
\hline D75 & Ac-HisH-AspH-Ser-Gly-Tyr- $\mathrm{NH}_{2}$ & -269.9 & 549.9 & -369.5 & 8 & 10 & -2.76 \\
\hline D76 & Ac-HisH-D-AspH-Ser-Gly-Tyr-NH ${ }_{2}$ & -274.0 & 534.2 & -368.8 & 8 & 10 & -2.95 \\
\hline D77 & Ac-His-Aspimide-Ser-Gly-Tyr- $\mathrm{NH}_{2}$ & -350.7 & 567.3 & -412.5 & 8 & 9 & -0.49 \\
\hline D78 & $\begin{array}{l}\text { Ac-His-D-Aspimide-Ser-Gly-Tyr- } \\
\mathrm{NH}_{2}\end{array}$ & -350.0 & 548.0 & -408.9 & 8 & 9 & -0.83 \\
\hline D79 & Ac-HisH-Aspimide-Ser-Gly-Tyr- $\mathrm{NH}_{2}$ & -207.3 & 564.2 & -310.2 & 8 & 9 & -2.21 \\
\hline D710 & $\begin{array}{l}\text { Ac-HisH-D-Aspimide-Ser-Gly-Tyr- } \\
\mathrm{NH}_{2}\end{array}$ & -212.6 & 545.8 & -306.4 & 8 & 9 & -2.34 \\
\hline D711 & Ac-His- $\beta$-Asp-Ser-Gly-Tyr- $\mathrm{NH}_{2}$ & -482.8 & 559.0 & -585.5 & 8 & 10 & -1.82 \\
\hline D712 & Ac-His-D $\beta$-Asp-Ser-Gly-Tyr- $\mathrm{NH}_{2}$ & -481.3 & 550.8 & -581.3 & 8 & 10 & -1.93 \\
\hline D713 & Ac-HisH- $\beta$-Asp-Ser-Gly-Tyr-NH ${ }_{2}$ & -388.6 & 568.8 & -476.0 & 8 & 10 & -1.57 \\
\hline D714 & Ac-HisH-D $\beta$-Asp-Ser-Gly-Tyr- $\mathrm{NH}_{2}$ & -386.9 & 547.8 & -474.8 & 8 & 10 & -2.04 \\
\hline D715 & Ac-HisH- $\beta$-AspH-Ser-Gly-Tyr- $\mathrm{NH}_{2}$ & -273.1 & 567.5 & -373.9 & 8 & 10 & -2.40 \\
\hline D716 & $\begin{array}{l}\text { Ac-HisH-D } \beta \text {-AspH-Ser-Gly-Tyr- } \\
\mathrm{NH}_{2}\end{array}$ & -273.9 & 562.5 & -370.8 & 8 & 10 & -2.40 \\
\hline
\end{tabular}

Hf: Heat of formation; Clog P: Calculated log P.

Histidine (HisH) and Aspartic acid (AspH): side chains are protonated.

All the amino acids without heading D- have L-chirality.; Aspimide has an imide structure.

Heading only $\beta$ is $\beta$-carboxy of L-Asp making peptide bond with Ala residue.

Heading $D-\beta$ is $\beta$-carboxy of $D$-Asp making peptide bond with Ala residue. 


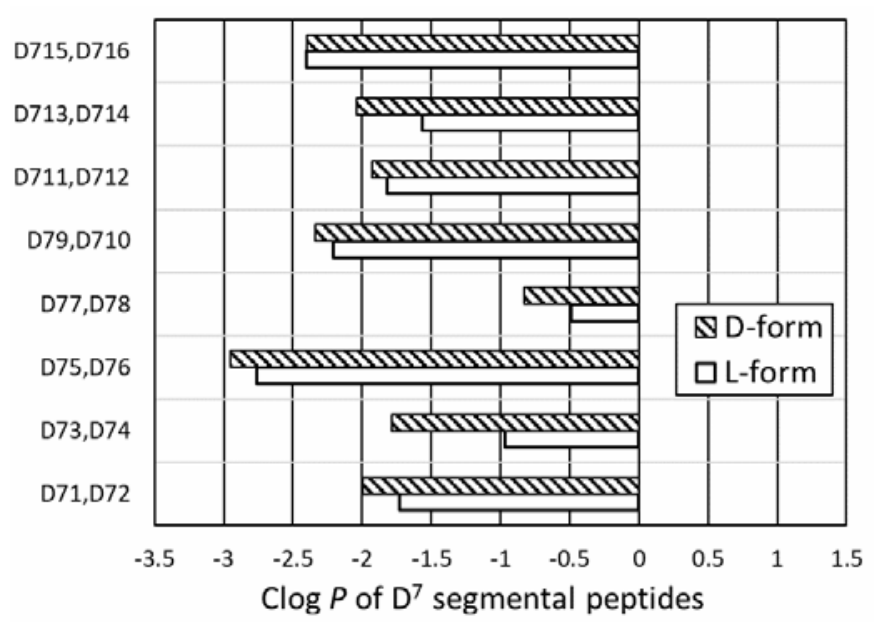

Figure 5. Comparison of Clog $P$ values between the L-epimer and D-epimer of the sequences $\mathrm{H}^{6} \mathrm{D}^{7}$ to $\mathrm{Y}^{10}$ including isomerized Asp residues in Amyloid $\beta 42$.

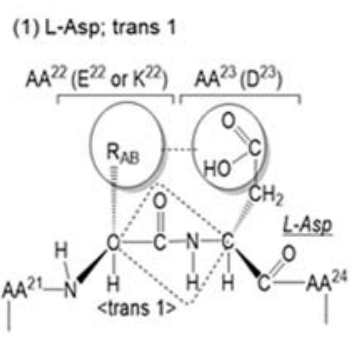

(5) L-Asp imide; trans 1

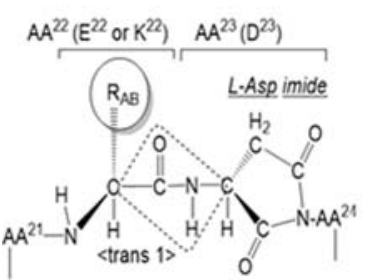

(9) L-Asp $\beta$; trans 1

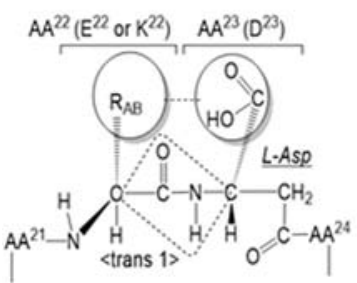

Interaction between $\mathrm{E}^{22}$ and $\mathrm{D}^{23}$

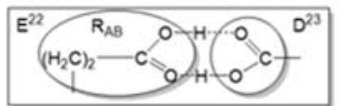

(2) D-Asp; trans 1

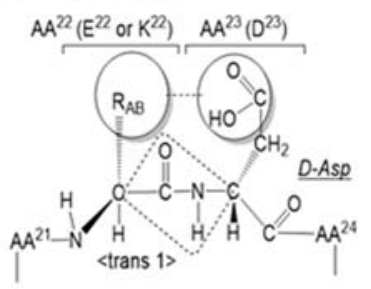

(6) D-Asp imide; trans 1

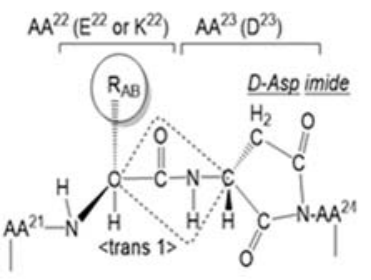

(10) D-Asp $\beta$; trans 1

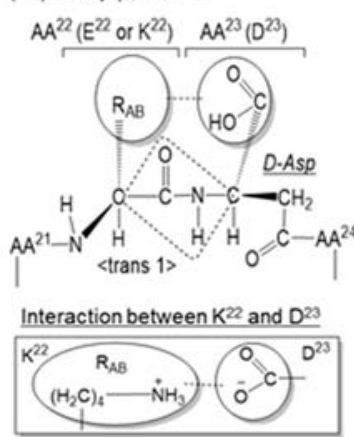

(3) L-Asp; trans 2

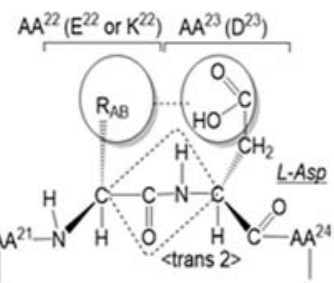

(7) L-Asp imide; trans 2

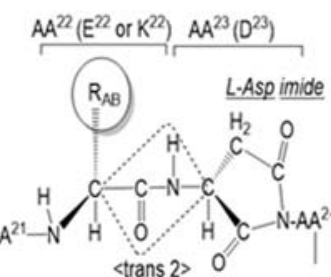

(11) L-Asp $\beta$; trans 2

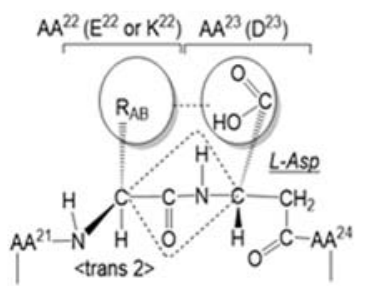

Interaction between $E^{22}$ and imide $D^{23}$

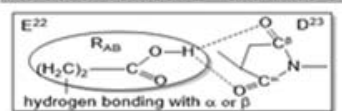

(4) D-Asp; trans 2

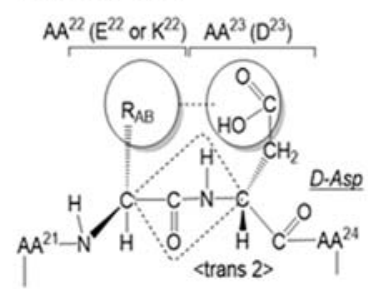

(8) D-Asp imide; trans 2

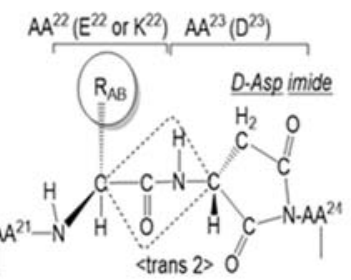

(12) D-Asp $\beta$; trans 2

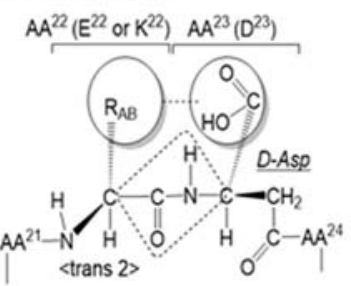

Interaction between $\mathrm{K}^{22}$ and imide $\mathrm{D}^{23}$

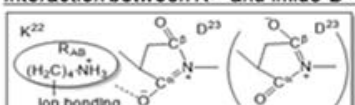

Figure 6. Chemical structures of the segmental peptides of Amyloid $\beta 42$ wild-type and Italian mutant epimers having L-Asp or D-Asp at $\mathrm{D}^{23}$. a) The structures trans 1 and trans 2 have different conformational peptide bonds. b) No. (1) to (4) are usual $\alpha$-carboxy of Asp making a peptide bond. c) No. (5) to (8) are structures in which $\mathrm{D}^{23}$ residue has an imide structure. d) No. (9) to (12) are $\beta$-carboxy of Asp making a peptide bond. The interactions between the side chains of $\mathrm{K}^{22}$ and $\mathrm{D}^{23}$ are ion bonding or hydrogen bonding. 
and $\mathrm{AA}^{23}$ are assumed to be hydrogen bonding between the side-chain carboxy group of $\mathrm{E}^{22}$ and $\mathrm{D}^{23}$, and ionic bonding between the ammonium cation of $\mathrm{K}^{22}$ and carboxylate anion of $\mathrm{D}^{23}$.

\subsection{Comparing $C \log P$ values of the segmental dipeptides of the wild-type Amyloid $\beta 42$ with those of the Italian mutant}

Values of Clog $P$ for $N$-acetyl-Glutamic-Asparticamide, $N$-acetyl-Lysine-Aspartic-amide, and their derivatives including epimers are shown in Table 4 and Figure 7.

The compounds numbered D231 to D234 and KD231 to KD234 do not have the structure according to the interaction between the side chains but have protonated side chains. The amino acids possessing free carboxylate anion $\left(\mathrm{Glu}^{-}\right.$and Asp $^{-}$) have a little outlier from the relationship between Exptl. $\log P$ and $C \log P$ as shown in Table 1 and Figure 3, whereas Exptl. Log $P$ values of the protonated amino acids (GluH and AspH) may have better homology with Clog $P$ values. Therefore, $C \log P$ values of amino acids and peptides having protonated side chains must be more homologous to Exptl. Log $P$ values. In this paper, the protonated side chains are considered as the typical model structure for the segmental peptides to estimate Exptl. Log $P$ values. In Figure 7, the results of Clog $P$ values are arranged comparing the results of the L-form epimers with that of the D-form epimer at $\mathrm{D}^{23}$.

Observing the data for the structures based on the wild type of Amyloid $\beta 42$, a little higher hydrophilicity can be seen in the models (D235 to D2312) formed by the interaction between the side chains than in the models (D231 to D234) formed without the interaction between the side chains. On the other hand, the Italian mutant segment models have inverse results compared with those of the wild-type segment. Values of Clog $P$ of the models KD235 to KD2312 showed higher hydrophobicity than the models KD231 to KD234.

\subsection{Comparing $C \log P$ values of the segmental dipeptide imides of the wild-type Amyloid $\beta 42$ with those of the Italian mutant}

Table 5 and Figure 8 show the data about the dipeptide imide structures of the wild type and
Italian mutant. The dipeptide imides of the wild type showed values in the range -2.80 to -2.10 . The dipeptide imides of the Italian mutant showed values in the range -3.32 to -2.75 . The dipeptide imides of the Italian mutant were generally more hydrophilic than those of the wild type. The larger and hydrophobic $C \log P$ values for the dipeptide segments of the wild type were obtained in the imide models (D2313 to D2322) than in the straight models (D233 to D2312). The smaller and more hydrophilic Clog $P$ values for the dipeptide segments of the Italian mutant were obtained in the imide models (KD2313 to KD2322) than in the straight models (KD235 to KD2312). D-epimers and L-epimers of the wild type gave similar Clog $P$ values except for D2319 to D2322, which have hydrogen bonding between the $\beta$ carbonyl group of the imide and the side-chain carboxy group of GluH. Most of the L-epimers of the Italian mutant gave larger Clog $P$ values than the D-epimers except for KD2319 and KD2320.

\subsection{Comparing Clog $P$ values of the segmental tripeptides of the wild-type Amyloid $\beta 42$ with those of the Italian mutant}

Table 6 and Figure 9 show data about the straight tripeptide structures of the wild type and Italian mutant of Amyloid $\beta 42$. Comparing Clog $P$ values of the wild type (D2323 to D2330) with those of the Italian mutant (KD2323 to KD2330), higher hydrophobicity can be seen in the Italian mutant (KD2323 to KD2330) (-1.53 to -0.44$)$ than the models (D2323 to D2330) (-2.05 to -1.43$)$ in the wild type. In the segments of the wild type, the D-epimer gave larger Clog $P$ values than the L-epimer except for the pair of D2325 and D2326. In the segments of the Italian mutant, the D-epimer gave larger Clog $P$ values than the L-epimer except for the pair of KD2325 and KD2326. These segmental peptides have the trans 2 structure.

\subsection{Comparing $C \log P$ values of the segmental tripeptide imides of the wild-type Amyloid $\beta 42$ with those of the Italian mutant}

Table 7 and Figure 10 show data for the tripeptide imide of the wild type and Italian mutant of Amyloid $\beta 42$. Comparing Clog $P$ values of the wild type (D2331 to D2338) with those of the 
Table 4. Calculated $\log P$ values of dipeptides isomerized at $D^{23}$ in the wild and Italian mutant of Amyloid $\beta 42$.

\begin{tabular}{|c|c|c|c|c|c|c|c|}
\hline No. & $N$-Acetyl-Peptide amides & $\begin{array}{c}\text { A: } \\
\text { Hf in } \\
\text { vacuum } \\
\text { (kcal/ } \\
\text { mol) }\end{array}$ & $\begin{array}{c}\text { B: } \\
\text { Solvent } \\
\text { accessible } \\
\text { area }\left(\AA^{2}\right)\end{array}$ & $\begin{array}{c}\mathrm{C}: \\
\mathrm{Hf} \text { in } \\
\mathrm{H}_{2} \mathrm{O} \\
\text { (kcal/ } \\
\text { mol) }\end{array}$ & $\begin{array}{c}\text { D: } \\
\text { Number } \\
\text { of } N \\
\text { atom }\end{array}$ & $\begin{array}{c}\text { E: } \\
\text { Number } \\
\text { of } O \\
\text { atom }\end{array}$ & $\begin{array}{c}\text { Clog } \\
\mathbf{P}\end{array}$ \\
\hline D231 & Ac-GluH-L-AspH-NH${ }_{2}$ & -344.1 & 301.4 & -378.5 & 3 & 7 & -2.86 \\
\hline D232 & Ac-GluH-D-AspH-NH ${ }_{2}$ & -341.0 & 312.7 & -380.2 & 3 & 7 & -2.76 \\
\hline D233 & Ac-GluH-L- $\beta$ AspH-NH ${ }_{2}$ & -340.5 & 321.6 & -377.9 & 3 & 7 & -2.52 \\
\hline D234 & Ac-GluH-D- $\beta$ AspH-NH ${ }_{2}$ & -339.9 & 322.2 & -381.5 & 3 & 7 & -2.62 \\
\hline D235 & $\begin{array}{l}\text { Ac-GluH-L-AspH-NH} \\
\text { trans1 }\end{array}$ & -344.2 & 297.9 & -374.5 & 3 & 7 & -2.83 \\
\hline D236 & $\begin{array}{l}\text { Ac-GluH-D-AspH-NH } \\
\text { trans1 }\end{array}$ & -344.2 & 296.6 & -375.4 & 3 & 7 & -2.88 \\
\hline D237 & $\begin{array}{l}\text { Ac-GluH-L-AspH-NH}{ }_{2} \\
\text { trans2 }\end{array}$ & -340.1 & 291.5 & -375.1 & 3 & 7 & -3.10 \\
\hline D238 & Ac-GluH-D-AspH-NH ${ }_{2}$ trans2 & -340.3 & 288.7 & -367.7 & 3 & 7 & -2.96 \\
\hline D239 & Ac-GluH-L- $\beta$ AspH-NH ${ }_{2}$ trans1 & -342.4 & 283.3 & -379.5 & 3 & 7 & -3.33 \\
\hline D2310 & Ac-GluH-D- $\beta$ AspH-NH ${ }_{2}$ trans1 & -342.4 & 292.8 & -379.8 & 3 & 7 & -3.13 \\
\hline D2311 & $\begin{array}{l}\text { Ac-GluH-L- } \beta \text { AspH-NH} \\
\text { trans2 }\end{array}$ & -342.3 & 291.8 & -368.9 & 3 & 7 & -2.87 \\
\hline D2312 & $\begin{array}{l}\text { Ac-GluH-D- } \beta \text { AspH-NH} \\
\text { trans } 2\end{array}$ & -341.5 & 290.7 & -371.0 & 3 & 7 & -2.97 \\
\hline KD231 & Ac-LysH-L-AspH- $\mathrm{NH}_{2}$ & -127.1 & 320.8 & -197.6 & 4 & 5 & -3.14 \\
\hline KD232 & Ac-LysH-D-AspH- $\mathrm{NH}_{2}$ & -125.4 & 318.9 & -194.9 & 4 & 5 & -3.16 \\
\hline KD233 & Ac-LysH-L- $\beta$ AspH-NH & -119.9 & 325.9 & -204.1 & 4 & 5 & -3.42 \\
\hline KD234 & Ac-LysH-D- $\beta$ AspH-NH & -112.1 & 343.1 & -205.6 & 4 & 5 & -3.33 \\
\hline KD235 & Ac-LysH-L-Asp- $\mathrm{NH}_{2}$ trans1 & -254.9 & 319.3 & -318.6 & 4 & 5 & -2.49 \\
\hline KD236 & Ac-LysH-D-Asp-NH $\mathrm{N}_{2}$ trans1 & -262.1 & 319.7 & -308.0 & 4 & 5 & -1.98 \\
\hline KD237 & Ac-LysH-L-Asp- $\mathrm{NH}_{2}$ trans2 & -260.3 & 316.5 & -309.6 & 4 & 5 & -2.15 \\
\hline KD238 & Ac-LysH-D-Asp- $\mathrm{NH}_{2}$ trans2 & -257.0 & 314.7 & -298.3 & 4 & 5 & -1.99 \\
\hline KD239 & Ac-LysH-L- $\beta$ Asp- $\mathrm{NH}_{2}$ trans1 & -260.4 & 317.6 & -312.5 & 4 & 5 & -2.20 \\
\hline KD2310 & Ac-LysH-D- $\beta$ Asp- $\mathrm{NH}_{2}$ trans1 & -259.9 & 314.1 & -311.1 & 4 & 5 & -2.25 \\
\hline KD2311 & Ac-LysH-L- $\beta$ Asp- $\mathrm{NH}_{2}$ trans2 & -257.1 & 314.9 & -304.8 & 4 & 5 & -2.15 \\
\hline KD2312 & Ac-LysH-D- $\beta$ Asp- $\mathrm{NH}_{2}$ trans2 & -255.7 & 320.1 & -313.7 & 4 & 5 & -2.32 \\
\hline
\end{tabular}

Hf: Heat of formation; Clog P: Calculated $\log$ P.

GluH (Glutamic acid) and AspH (Aspartic acid) of which side chains protonated and liked with hydrogen bonding. LysH (Lysine) and AspH (Aspartic acid) of which side chains are protonated and linked with ionic bonding.

All the amino acids without heading D- have L-chirality.; Aspimide has an imide structure.

Heading only $\beta$ is $\beta$-carboxy of L-Asp making peptide bond with Ala residue.

Heading $D-\beta$ is $\beta$-carboxy of D-Asp making peptide bond with Ala residue. 


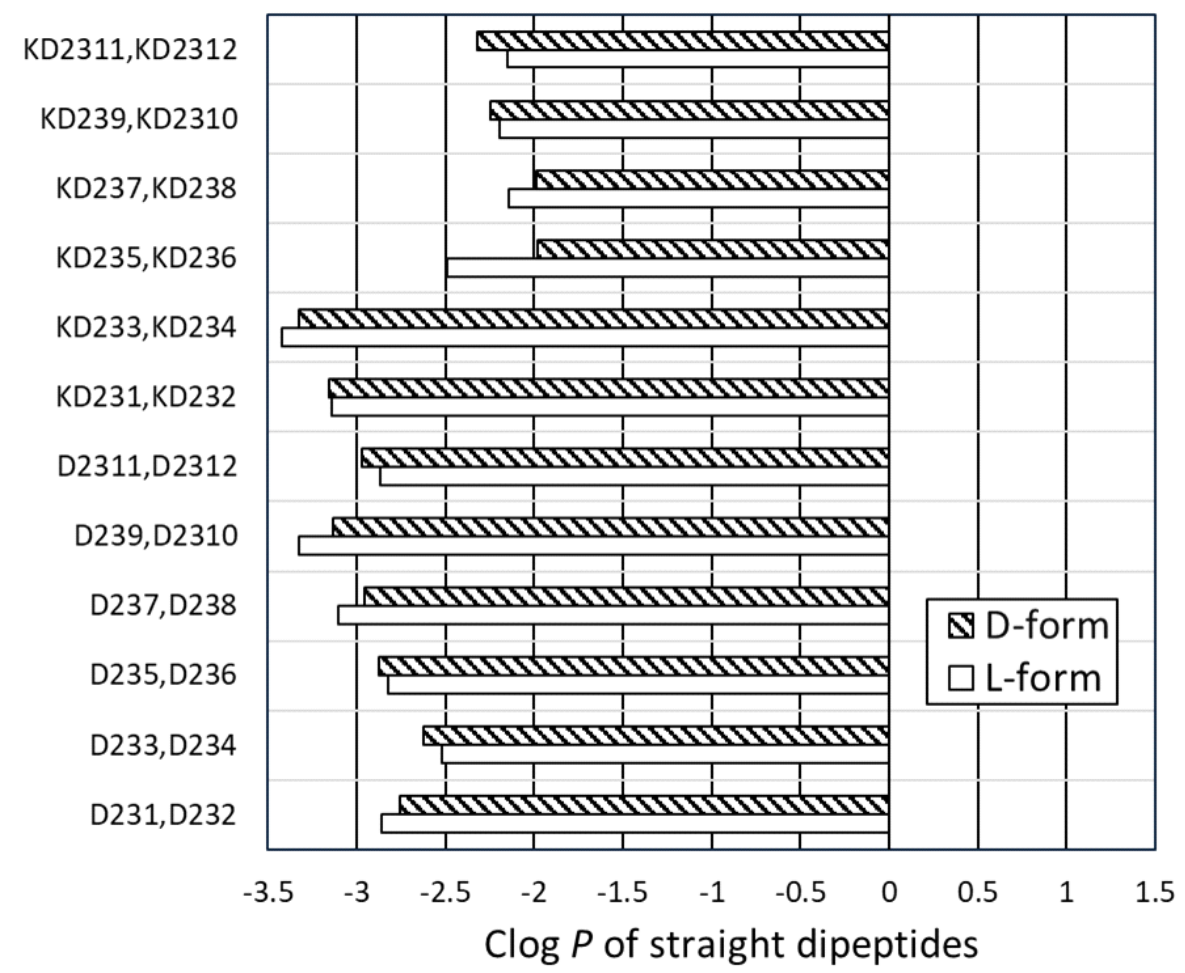

Figure 7. Comparison between Clog $P$ values of the dipeptide segment models of Ac- $\mathrm{E}^{22}-\mathrm{D}^{23}-\mathrm{NH}_{2}$ (the wild type of Amyloid $\beta 42$ ) and Ac- $\mathrm{K}^{22}-\mathrm{D}^{23}-\mathrm{NH}_{2}$ (Italian mutant) as well as between the L-epimer and D-epimer.

Table 5. Calculated $\log P$ values of dipeptide imides at $\mathrm{D}^{23}$ in the wild and Italian mutant of Amyloid $\beta 42$.

\begin{tabular}{|c|c|c|c|c|c|c|c|}
\hline No. & $N$-Acetyl-Peptide amides & $\begin{array}{c}\text { A: } \\
\text { Hf in } \\
\text { vacuum } \\
\text { (kcal/ } \\
\text { mol) }\end{array}$ & $\begin{array}{c}\text { B: } \\
\text { Solvent } \\
\text { accessible } \\
\text { area }\left(\AA^{2}\right)\end{array}$ & $\begin{array}{c}\mathrm{C}: \\
\mathrm{Hf} \text { in } \\
\mathrm{H}_{2} \mathbf{O} \\
(\mathbf{k c a l} / \\
\text { mol) }\end{array}$ & $\begin{array}{c}\text { D: } \\
\text { Number } \\
\text { of } N \\
\text { atom }\end{array}$ & $\begin{array}{c}\text { E: } \\
\text { Number } \\
\text { of } O \\
\text { atom }\end{array}$ & $\mathrm{Clog} P$ \\
\hline D2313 & Ac-GluH-L-Aspimide-NH & -282.6 & 305.3 & -314.5 & 3 & 6 & -2.26 \\
\hline D2314 & Ac-GluH-D-Aspimide-NH & -281.9 & 305.2 & -314.0 & 3 & 6 & -2.26 \\
\hline D2315 & $\begin{array}{l}\text { Ac-GluH-L-Aspimide } \alpha \mathrm{H}- \\
\mathrm{NH} \text { trans1 }\end{array}$ & -278.8 & 302.8 & -313.7 & 3 & 6 & -2.40 \\
\hline D2316 & $\begin{array}{l}\text { Ac-GluH-D-Aspimide } \alpha \mathrm{H}- \\
\mathrm{NH} \text { trans1 }\end{array}$ & -280.5 & 293.9 & -313.2 & 3 & 6 & -2.53 \\
\hline D2317 & $\begin{array}{l}\text { Ac-GluH-L-Aspimide } \alpha \mathrm{H}- \\
\mathrm{NH} \text { trans2 }\end{array}$ & -277.5 & 295.6 & -315.1 & 3 & 6 & -2.64 \\
\hline D2318 & $\begin{array}{l}\text { Ac-GluH-D-Aspimide } \alpha \mathrm{H}- \\
\mathrm{NH} \text { trans } 2\end{array}$ & -275.4 & 301.5 & -315.6 & 3 & 6 & -2.59 \\
\hline D2319 & $\begin{array}{l}\text { Ac-GluH-L-Aspimide } \beta \mathrm{H}- \\
\mathrm{NH} \text { trans1 }\end{array}$ & -282.6 & 303.3 & -307.0 & 3 & 6 & -2.10 \\
\hline D2320 & $\begin{array}{l}\text { Ac-GluH-D-Aspimide } \beta \mathrm{H}- \\
\mathrm{NH} \text { trans1 }\end{array}$ & -281.6 & 301.2 & -312.8 & 3 & 6 & -2.36 \\
\hline
\end{tabular}


Table 5 continued..

\begin{tabular}{|c|c|c|c|c|c|c|c|}
\hline No. & $N$-Acetyl-Peptide amides & $\begin{array}{c}\text { A: } \\
\text { Hf in } \\
\text { vacuum } \\
\text { (kcal/ } \\
\text { mol) }\end{array}$ & $\begin{array}{c}\text { B: } \\
\text { Solvent } \\
\text { accessible } \\
\text { area }\left(\AA^{2}\right)\end{array}$ & $\begin{array}{c}\mathrm{C}: \\
\mathrm{Hf} \text { in } \\
\mathrm{H}_{2} \mathrm{O} \\
(\mathrm{kcal} / \\
\mathrm{mol})\end{array}$ & $\begin{array}{c}\text { D: } \\
\text { Number } \\
\text { of } N \\
\text { atom }\end{array}$ & $\begin{array}{c}\text { E: } \\
\text { Number } \\
\text { of } O \\
\text { atom }\end{array}$ & $\mathbf{C l o g} \mathbf{P}$ \\
\hline D2321 & $\begin{array}{l}\text { Ac-GluH-L-Aspimide } \beta \text { H- } \\
\text { NH trans } 2\end{array}$ & -273.1 & 286.2 & -308.9 & 3 & 6 & -2.80 \\
\hline D2322 & $\begin{array}{l}\text { Ac-GluH-D-Aspimide } \beta \mathrm{H}- \\
\text { NH trans2 }\end{array}$ & -283.4 & 297.7 & -316.7 & 3 & 6 & -2.45 \\
\hline KD2313 & Ac-LysH-L-Aspimide-NH & -44.4 & 325.1 & -144.5 & 4 & 4 & -3.32 \\
\hline KD2314 & Ac-LysH-D-Aspimide-NH & -54.6 & 321.0 & -144.3 & 4 & 4 & -3.09 \\
\hline KD2315 & $\begin{array}{l}\text { Ac-LysH-L-Aspimide } \alpha \mathrm{H}- \\
\text { NH trans1 }\end{array}$ & -65.6 & 304.7 & -136.3 & 4 & 4 & -2.89 \\
\hline KD2316 & $\begin{array}{l}\text { Ac-LysH-D-Aspimide } \alpha \mathrm{H}- \\
\text { NH trans1 }\end{array}$ & -63.3 & 301.9 & -126.1 & 4 & 4 & -2.75 \\
\hline KD2317 & $\begin{array}{l}\text { Ac-LysH-L-Aspimide } \alpha \mathrm{H}- \\
\mathrm{NH} \text { trans } 2\end{array}$ & -63.8 & 301.3 & -138.0 & 4 & 4 & -3.07 \\
\hline KD2318 & $\begin{array}{l}\text { Ac-LysH-D-Aspimide } \alpha \mathrm{H}- \\
\mathrm{NH} \text { trans } 2\end{array}$ & -59.2 & 311.4 & -136.1 & 4 & 4 & -2.94 \\
\hline KD2319 & $\begin{array}{l}\text { Ac-LysH-L-Aspimide } \beta \mathrm{H}- \\
\mathrm{NH} \text { trans1 }\end{array}$ & -63.6 & 318.3 & -148.4 & 4 & 4 & -2.98 \\
\hline KD2320 & $\begin{array}{l}\text { Ac-LysH-D-Aspimide } \beta \text { H- } \\
\text { NH trans1 }\end{array}$ & -60.1 & 300.9 & -132.7 & 4 & 4 & -3.05 \\
\hline KD2321 & $\begin{array}{l}\text { Ac-LysH-L-Aspimide } \beta \text { H- } \\
\text { NH trans } 2\end{array}$ & -46.1 & 303.9 & -125.6 & 4 & 4 & -3.22 \\
\hline KD2322 & $\begin{array}{l}\text { Ac-LysH-D-Aspimide } \beta \text { H- } \\
\text { NH trans } 2\end{array}$ & -56.2 & 301.5 & -130.8 & 4 & 4 & -3.10 \\
\hline
\end{tabular}

Hf: Heat of formation; Clog P: Calculated log P.

GluH (Glutamic acid) and AspH (Aspartic acid) of which side chains protonated and liked with hydrogen bonding except of D2313 and D2314. LysH (Lysine) and AspH (Aspartic acid) of which side chains are protonated and linked with ionic bonding except of KW2313 and KD2314. All the amino acids without heading D- have Lchirality. Aspimide $\alpha \mathrm{H}$ has an imide structure of which $\alpha$-carbonyl oxygen makes a bonding with the side chain of GluH or LysH. Aspimide $\beta \mathrm{H}$ has an imide structure of which $\beta$-carbonyl oxygen makes a bonding with the side chain of GluH or LysH. Heading only $\beta$ is $\beta$-carboxy of L-Asp making peptide bond with Ala residue. Heading D- $\beta$ is $\beta$-carboxy of $\mathrm{D}$-Asp making peptide bond with Ala residue.

Italian mutant (KD2331 to KD2338), larger Clog $P$ values can be seen in the models D2331 to D2338 $(-2.14$ to -1.14$)$ in the wild type than in the Italian mutant (KD2331 to KD2338) (-2.20 to -1.80).

Comparing the Clog $P$ values of the straight tripeptide and imide of the wild type, the Clog $P$ values from the imide (D2331 to D2338) ( -2.14 to -1.14) was a little larger than that of the straight tripeptides (D2323 to D2330) (-2.05 to -1.43) as shown in Table 6 and Figure 9. In the case of the Italian mutant, the Clog $P$ values from the straight tripeptides (KD2323 to KD2330) (-1.53 to -0.44) was larger than that of the imide (KD2331 to KD2338) (-2.20 to -1.80$)$ as shown in Table 6 and Figure 9. D-epimers and L-epimers gave different Clog $P$ values depending on the structure. 


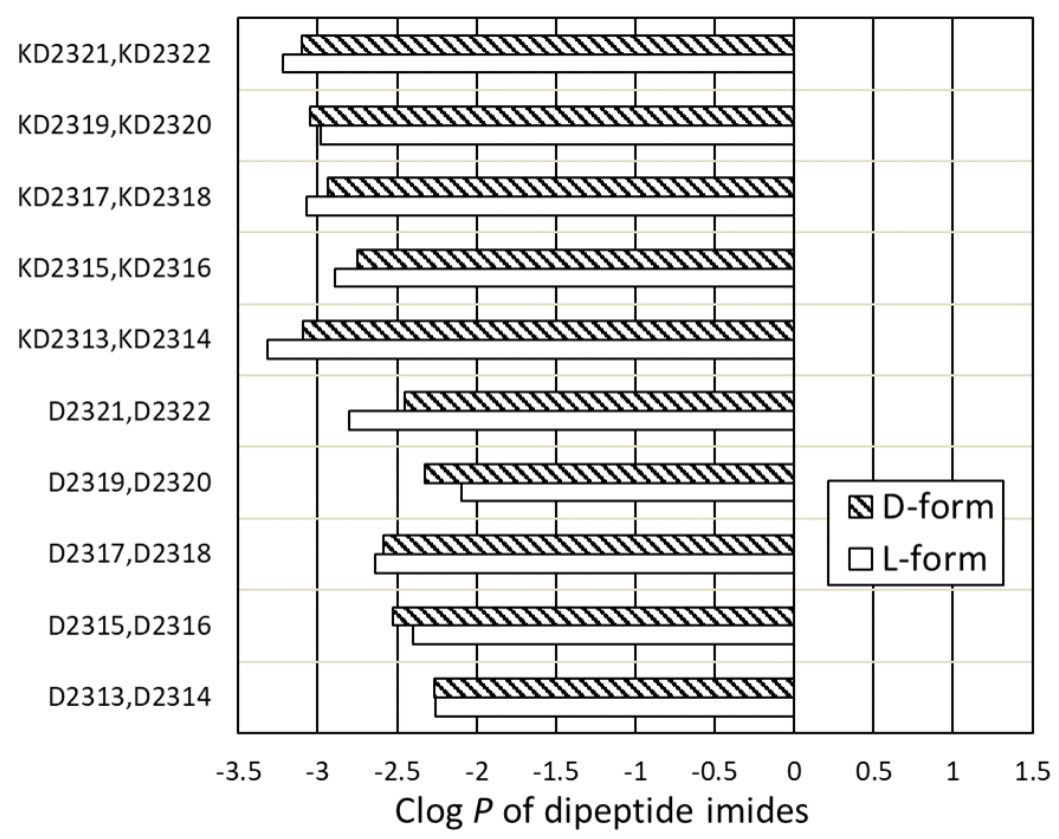

Figure 8. Clog $P$ values of the dipeptide imide models of Ac- $\mathrm{E}^{22}-\mathrm{D}^{23}-\mathrm{NH}_{2}$ (the wild type) and Ac- $\mathrm{K}^{22}-\mathrm{D}^{23}-\mathrm{NH}_{2}$ (Italian mutant) as well as comparing the L-epimer and D-epimer.

Table 6. Calculated $\log P$ values of tripeptides isomerized at $D^{23}$ in the wild and Italian mutant of Amyloid $\beta 42$.

\begin{tabular}{|c|c|c|c|c|c|c|c|}
\hline No. & $N$-Acetyl-Peptide amides & $\begin{array}{c}\text { A: } \\
\text { Hf in } \\
\text { vacuum } \\
\text { (kcal/ } \\
\text { mol) }\end{array}$ & $\begin{array}{l}\text { B: Solvent } \\
\text { accessible } \\
\text { area }\left(\AA^{2}\right)\end{array}$ & $\begin{array}{c}\mathrm{C}: \\
\mathrm{Hf} \text { in } \\
\mathrm{H}_{2} \mathrm{O} \\
\text { (kcal/ } \\
\text { mol) }\end{array}$ & $\begin{array}{c}\text { D: } \\
\text { Number } \\
\text { of } N \\
\text { atom }\end{array}$ & $\begin{array}{c}\text { E: } \\
\text { Number } \\
\text { of } O \\
\text { atom }\end{array}$ & Clog \\
\hline D2323 & $\begin{array}{l}\text { Ac-GluH-L-AspH-Val-NH } \\
\text { trans1 }\end{array}$ & -393.9 & 387.4 & -437.6 & 4 & 8 & -2.05 \\
\hline D2324 & $\begin{array}{l}\text { Ac-GluH-D-AspH-Val- } \mathrm{NH}_{2} \\
\text { trans1 }\end{array}$ & -398.4 & 400.6 & -433.7 & 4 & 8 & -1.53 \\
\hline D2325 & $\begin{array}{l}\text { Ac-GluH-L-AspH-Val- } \mathrm{NH}_{2} \\
\text { trans2 }\end{array}$ & -395.5 & 407.2 & -432.0 & 4 & 8 & -1.43 \\
\hline D2326 & $\begin{array}{l}\text { Ac-GluH-D-AspH-Val- } \mathrm{NH}_{2} \\
\text { trans2 }\end{array}$ & -399.1 & 373.5 & -431.5 & 4 & 8 & -2.03 \\
\hline D2327 & $\begin{array}{l}\text { Ac-GluH-L- } \beta \text { AspH-Val-NH } \\
\text { trans1 }\end{array}$ & -393.9 & 393.6 & -438.3 & 4 & 8 & -1.94 \\
\hline D2328 & $\begin{array}{l}\text { Ac-GluH-D- } \beta \text { AspH-Val- } \mathrm{NH}_{2} \\
\text { trans1 }\end{array}$ & -391.1 & 393.3 & -432.2 & 4 & 8 & -1.87 \\
\hline D2329 & $\begin{array}{l}\text { Ac-GluH-L- } \beta \text { AspH-Val- } \mathrm{NH}_{2} \\
\text { trans2 }\end{array}$ & -396.0 & 383.4 & -428.9 & 4 & 8 & -1.84 \\
\hline D2330 & $\begin{array}{l}\text { Ac-GluH-D- } \beta \text { AspH-Val- } \mathrm{NH}_{2} \\
\text { trans2 }\end{array}$ & -391.5 & 405.5 & -433.5 & 4 & 8 & -1.63 \\
\hline KD2323 & $\begin{array}{l}\text { Ac-LysH-L-Asp-Val-NH }{ }_{2} \\
\text { trans1 }\end{array}$ & -318.8 & 380.8 & -361.0 & 5 & 6 & -1.40 \\
\hline
\end{tabular}


Table 6 continued..

\begin{tabular}{|c|c|c|c|c|c|c|c|}
\hline No. & $N$-Acetyl-Peptide amides & $\begin{array}{c}\text { A: } \\
\text { Hf in } \\
\text { vacuum } \\
\text { (kcal/ } \\
\text { mol) }\end{array}$ & $\begin{array}{l}\text { B: Solvent } \\
\text { accessible } \\
\text { area }\left(\AA^{2}\right)\end{array}$ & $\begin{array}{c}\mathrm{C}: \\
\mathrm{Hf} \text { in } \\
\mathrm{H}_{2} \mathrm{O} \\
\text { (kcal/ } \\
\text { mol) }\end{array}$ & $\begin{array}{c}\text { D: } \\
\text { Number } \\
\text { of } N \\
\text { atom }\end{array}$ & $\begin{array}{c}\text { E: } \\
\text { Number } \\
\text { of } O \\
\text { atom }\end{array}$ & $\underset{\mathbf{P}}{\text { Clog }}$ \\
\hline KD2324 & $\begin{array}{l}\text { Ac-LysH-D-Asp-Val-NH } \\
\text { trans1 }\end{array}$ & -320.5 & 409.5 & -370.3 & 5 & 6 & -0.98 \\
\hline KD2325 & $\begin{array}{l}\text { Ac-LysH-L-Asp-Val-NH }{ }_{2} \\
\text { trans2 }\end{array}$ & -319.3 & 394.4 & -370.8 & 5 & 6 & -1.35 \\
\hline KD2326 & $\begin{array}{l}\text { Ac-LysH-D-Asp-Val-NH }{ }_{2} \\
\text { trans2 }\end{array}$ & -312.9 & 394.2 & -369.8 & 5 & 6 & -1.53 \\
\hline KD2327 & $\begin{array}{l}\text { Ac-LysH-L- } \beta \text { Asp-Val-NH } \\
\text { trans1 }\end{array}$ & -366.9 & 482.2 & -432.6 & 6 & 7 & -0.62 \\
\hline KD2328 & $\begin{array}{l}\text { Ac-LysH-D- } \beta \text { Asp-Val-NH } \\
\text { trans1 }\end{array}$ & -367.4 & 464.8 & -414.3 & 6 & 7 & -0.48 \\
\hline KD2329 & $\begin{array}{l}\text { Ac-LysH-L- } \beta \text { Asp-Val-NH }{ }_{2} \\
\text { trans2 }\end{array}$ & -361.2 & 469.7 & -409.0 & 6 & 7 & -0.44 \\
\hline KD2330 & $\begin{array}{l}\text { Ac-LysH-D- } \beta \text { Asp-Val-NH } \\
\text { trans2 }\end{array}$ & -360.8 & 479.4 & -418.7 & 6 & 7 & -0.50 \\
\hline
\end{tabular}

Hf: Heat of formation; Clog P: Calculated log P.

GluH (Glutamic acid) and AspH (Aspartic acid) of which side chains protonated and liked with hydrogen bonding. LysH (Lysine) and AspH (Aspartic acid) of which side chains are protonated and linked with ionic bonding. Heading only $\beta$ is $\beta$-carboxy of L-Asp making peptide bond with Ala residue.

Heading D- $\beta$ is $\beta$-carboxy of D-Asp making peptide bond with Ala residue.

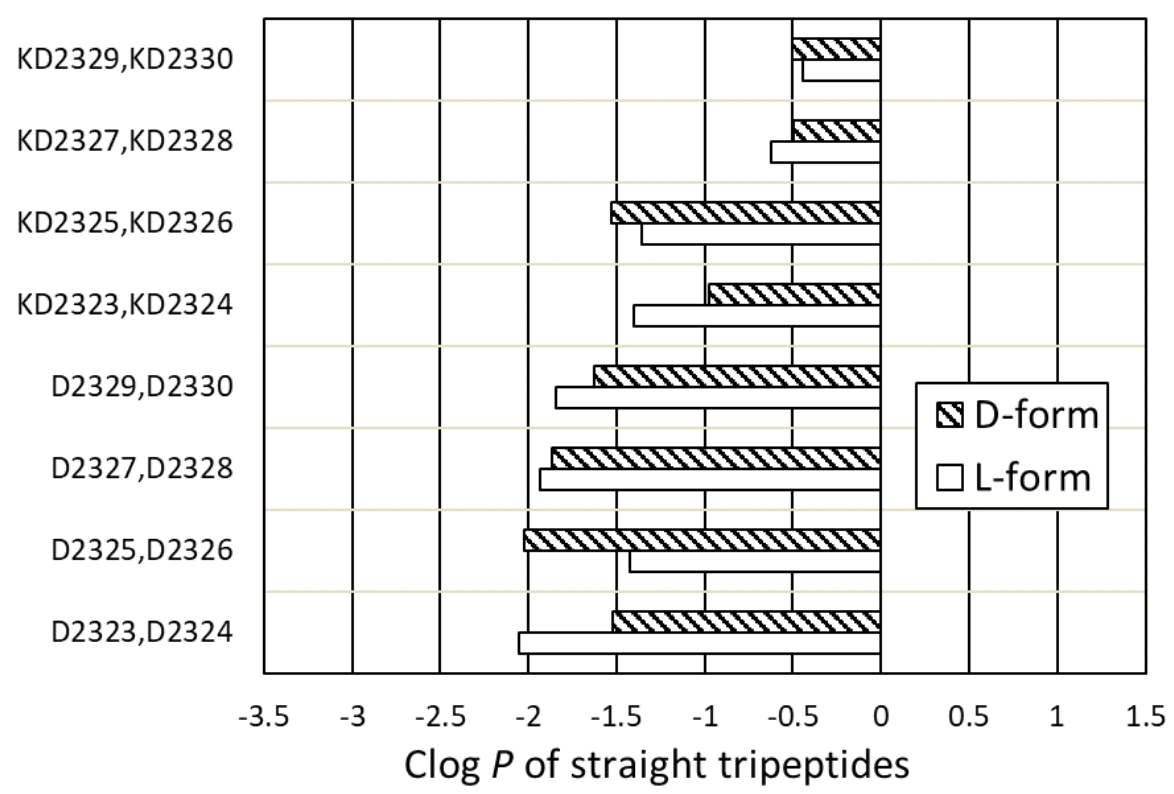

Figure 9. Clog $P$ values of the tripeptide segment models of $A c-E^{22}-D^{23}-V^{24}-N_{2}$ (the wild type) and $\mathrm{Ac}-\mathrm{K}^{22}-\mathrm{D}^{23}-\mathrm{V}^{24}-\mathrm{NH}_{2}$ (Italian mutant) as well as comparing the L-epimer and D-epimer. 
Table 7. Calculated $\log P$ values of tripeptide imides at $D^{23}$ in the wild and Italian mutant of Amyloid $\beta 42$.

\begin{tabular}{|c|c|c|c|c|c|c|c|}
\hline No. & $N$-Acetyl-Peptide amides & $\begin{array}{c}\text { A: } \\
\text { Hf in } \\
\text { vacuum } \\
\text { (kcal/ } \\
\text { mol) }\end{array}$ & $\begin{array}{c}\text { B: } \\
\text { Solvent } \\
\text { accessible } \\
\text { area }\left(\AA^{2}\right)\end{array}$ & $\begin{array}{c}\mathrm{C}: \\
\mathrm{Hf} \text { in } \\
\mathrm{H}_{2} \mathrm{O} \\
\text { (kcal/mol) }\end{array}$ & $\begin{array}{c}\text { D: } \\
\text { Number } \\
\text { of } N \\
\text { atom }\end{array}$ & $\begin{array}{c}\text { E: } \\
\text { Number } \\
\text { of } O \\
\text { atom }\end{array}$ & Clog \\
\hline D2331 & $\begin{array}{l}\text { Ac-GluH-L-Aspimide } \alpha \mathrm{H} \text { - } \\
\text { Val- } \mathrm{NH}_{2} \text { trans } 1\end{array}$ & -335.2 & 389.4 & -370.2 & 4 & 7 & -1.36 \\
\hline D2332 & $\begin{array}{l}\text { Ac-GluH-D-Aspimide } \alpha \mathrm{H} \text { - } \\
\text { Val- } \mathrm{NH}_{2} \text { trans1 }\end{array}$ & 356.3 & -377.5 & -277.6 & 4 & 7 & -2.14 \\
\hline D2333 & $\begin{array}{l}\text { Ac-GluH-L-Aspimide } \alpha \mathrm{H} \text { - } \\
\text { Val- } \mathrm{NH}_{2} \text { trans2 }\end{array}$ & -333.3 & 384.5 & -370.0 & 4 & 7 & -1.52 \\
\hline D2334 & $\begin{array}{l}\text { Ac-GluH-D-Aspimide } \alpha \mathrm{H}- \\
\text { Val- } \mathrm{NH}_{2} \text { trans2 }\end{array}$ & -336.9 & 362.5 & -371.0 & 4 & 7 & -1.91 \\
\hline D2335 & $\begin{array}{l}\text { Ac-GluH-L-Aspimide } \beta \mathrm{H}- \\
\text { Val- } \mathrm{NH}_{2} \text { trans } 1\end{array}$ & -337.9 & 362.4 & -369.5 & 4 & 7 & -1.84 \\
\hline D2336 & $\begin{array}{l}\text { Ac-GluH-D-Aspimide } \beta \mathrm{H} \text { - } \\
\text { Val- } \mathrm{NH}_{2} \text { trans } 1\end{array}$ & -338.9 & 393.7 & -369.9 & 4 & 7 & -1.14 \\
\hline D2337 & $\begin{array}{l}\text { Ac-GluH-L-Aspimide } \beta \mathrm{H}- \\
\text { Val- } \mathrm{NH}_{2} \text { trans } 2\end{array}$ & -331.8 & 372.7 & -364.2 & 4 & 7 & -1.66 \\
\hline D2338 & $\begin{array}{l}\text { Ac-GluH-D-Aspimide } \beta \mathrm{H}- \\
\text { Val- } \mathrm{NH}_{2} \text { trans } 2\end{array}$ & -331.4 & 364.7 & -370.3 & 4 & 7 & -2.01 \\
\hline KD2331 & $\begin{array}{l}\text { Ac-LysH-L-Aspimide } \alpha \mathrm{H}- \\
\text { Val- } \mathrm{NH}_{2} \text { trans } 1\end{array}$ & -128.2 & 393.8 & -196.5 & 5 & 5 & -1.80 \\
\hline KD2332 & $\begin{array}{l}\text { Ac-LysH-D-Aspimide } \alpha \mathrm{H}- \\
\text { Val- } \mathrm{NH}_{2} \text { trans1 }\end{array}$ & -135.5 & 375.1 & -200.8 & 5 & 5 & -2.10 \\
\hline KD2333 & $\begin{array}{l}\text { Ac-LysH-L-Aspimide } \alpha \mathrm{H}- \\
\text { Val- } \mathrm{NH}_{2} \text { trans2 }\end{array}$ & -129.9 & 379.0 & -200.4 & 5 & 5 & -2.17 \\
\hline KD2334 & $\begin{array}{l}\text { Ac-LysH-D-Aspimide } \alpha \mathrm{H}- \\
\text { Val- } \mathrm{NH}_{2} \text { trans2 }\end{array}$ & -130.0 & 390.7 & -204.0 & 5 & 5 & -2.02 \\
\hline KD2335 & $\begin{array}{l}\text { Ac-LysH-L-Aspimide } \beta \mathrm{H}- \\
\text { Val- } \mathrm{NH}_{2} \text { trans } 1\end{array}$ & -127.3 & 388.8 & -207.5 & 5 & 5 & -2.20 \\
\hline KD2336 & $\begin{array}{l}\text { Ac-LysH-D-Aspimide } \beta \mathrm{H}- \\
\text { Val- } \mathrm{NH}_{2} \text { trans } 1\end{array}$ & -117.1 & 396.1 & -199.5 & 5 & 5 & -2.17 \\
\hline KD2337 & $\begin{array}{l}\text { Ac-LysH-L-Aspimide } \beta \mathrm{H}- \\
\text { Val- } \mathrm{NH}_{2} \text { trans } 2\end{array}$ & -121.8 & 371.6 & -177.2 & 5 & 5 & -1.96 \\
\hline KD2338 & $\begin{array}{l}\text { Ac-LysH-D-Aspimide } \beta \text { H- } \\
\text { Val- } \mathrm{NH}_{2} \text { trans } 2\end{array}$ & -113.7 & 375.0 & -176.2 & 5 & 5 & -2.11 \\
\hline
\end{tabular}

Hf: Heat of formation; Clog P: Calculated log P.

GluH (Glutamic acid) and AspH (Aspartic acid) of which side chains protonated and liked with hydrogen bonding. LysH (Lysine) and AspH (Aspartic acid) of which side chains are protonated and linked with ionic bonding. All the amino acids without heading D- have L-chirality. Aspimide $\alpha \mathrm{H}$ has an imide structure of which $\alpha$-carbonyl oxygen makes a bonding with the side chain of GluH or LysH. Aspimide $\beta \mathrm{H}$ has an imide structure of which $\beta$-carbonyl oxygen makes a bonding with the side chain of GluH or LysH.

Heading only $\beta$ is $\beta$-carboxy of L-Asp making peptide bond with Ala residue.

Heading $D \beta$ is $\beta$-carboxy of $D$-Asp making peptide bond with Ala residue. 


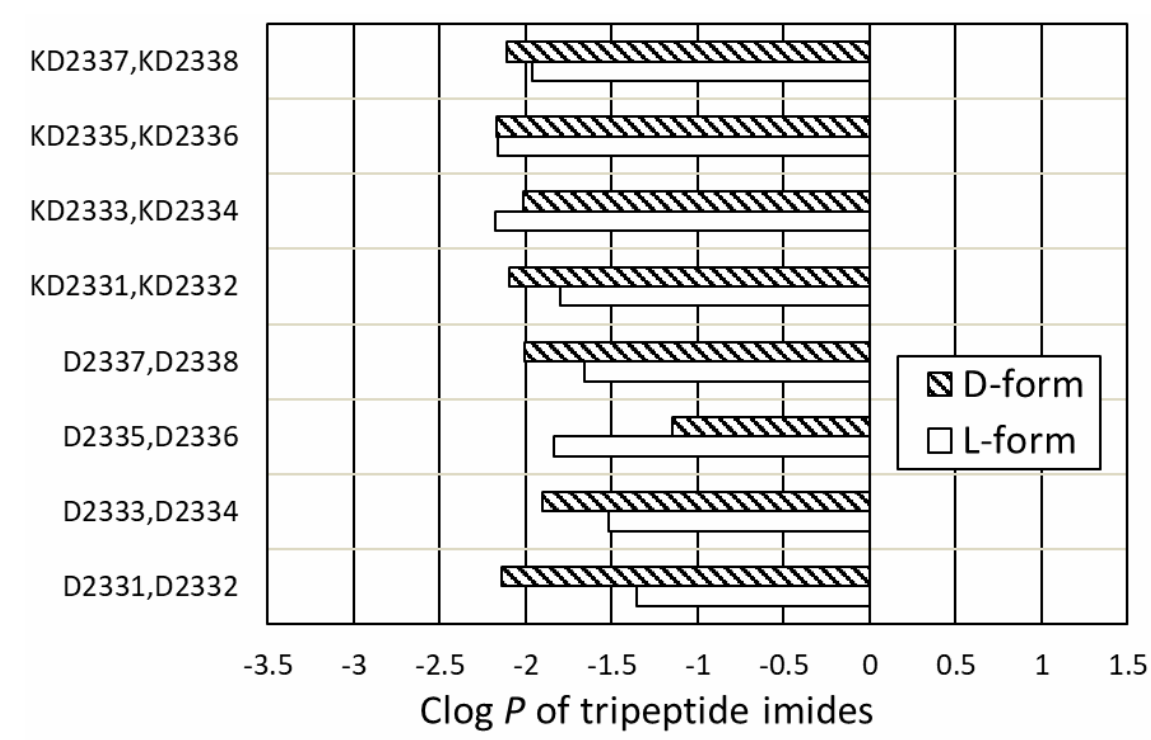

Figure 10. Clog $P$ values of the tripeptide imide models of $\mathrm{Ac}-\mathrm{E}^{22}-\mathrm{D}^{23}-\mathrm{V}^{24}-\mathrm{NH}_{2}$ (the wild type) and $\mathrm{Ac}-\mathrm{K}^{22}-\mathrm{D}^{23}-\mathrm{V}^{24}-\mathrm{NH}_{2}$ (Italian mutant) as well as comparing the L-epimer and D-epimer.

\subsection{Comparing $C \log P$ values of the segmental tetrapeptides of the wild-type Amyloid $\beta 42$ with those of the Italian mutant}

Table 8 and Figure 11 show data for the straight tetrapeptide structures of the wild type and Italian mutant of Amyloid $\beta 42$. Calculation was carried out for the segmental models having a hydrogen bond between $\mathrm{C}=\mathrm{O}$ of Ala residue and $\mathrm{NH}$ of Val residue. Comparing Clog $P$ values of the wild type (D2339 to D2346) with those of the Italian mutant (KD2339 to KD2346), higher hydrophobicity can be seen in the Italian mutant (KD2339 to KD2346) (-1.48 to -0.40$)$ than in the models D2339 to D2346 (-2.18 to -1.35$)$ in the wild type.

\subsection{Comparing Clog $P$ values of the segmental tetrapeptide imides of the wild-type Amyloid $\beta 42$ with those of the Italian mutant}

Table 9 and Figure 12 show data for the tetrapeptide imide of the wild type and Italian mutant of Amyloid $\beta 42$. These segmental models have no hydrogen bond between $\mathrm{C}=\mathrm{O}$ of Ala residue and $\mathrm{NH}$ of $\mathrm{Val}$ residue. Comparing Clog $P$ values of the wild type (D2347 to D2354) with those of the Italian mutant (KD2347 to KD2354), a little larger hydrophobicity can be seen in the models D2347 to D2354 (-1.36 to -0.60$)$ in the wild type than in the Italian mutant KD2347 to KD2354 (-2.10 to -1.18$)$.
Comparing the Clog $P$ values of the straight tetrapeptide and imide of the wild type, a little larger hydrophobicity as Clog $P$ value was obtained from the imide (D2347 to D2354) $(-1.36$ to -0.60 ) than the straight tripeptides (D2339 to D2346) (-2.18 to -1.35$)$. In the case of the Italian mutant, the larger hydrophobicity as $C \log P$ value was obtained from the straight tripeptides KD2339 to KD2346 ( -1.48 to -0.40$)$ than from the imide KD2347 to KD2354 ( -2.10 to -1.18$)$. D-Epimers and L-epimers gave similar Clog $P$ values.

\subsection{Comparing $C \log P$ values of the segmental hexapeptides of the wild type with those of the Italian mutant based on one or two hydrogen- bonding form}

The segmental hexapeptides with one or two hydrogen bonds are shown in Figure 13. The chemical structures of the segmental hexapeptides are classified into several forms: (1) wild type or Italian mutant, (2) L-form or D-form with $\mathrm{D}^{23}$ chirality, (3) trans 1 or trans 2, (4) $\alpha$-peptide or $\beta$-peptide, and (5) having one hydrogen bond (hydrogen bonding 1) or two hydrogen bonds (hydrogen bonding 1 and 2). These structures are constructed based on the assumption of the interaction between the side chain of $\mathrm{AA}^{22}$ and that of $\mathrm{D}^{23}$. 
Table 8. Calculated $\log P$ values of tetrapeptides isomerized at $D^{23}$ in the wild and Italian mutant of Amyloid $\beta 42$.

\begin{tabular}{|c|c|c|c|c|c|c|c|}
\hline No. & $N$-Acetyl-Peptide amides & $\begin{array}{c}\text { A: } \\
\text { Hf in } \\
\text { vacuum } \\
\text { (kcal/ } \\
\text { mol) }\end{array}$ & $\begin{array}{c}\text { B: } \\
\text { Solvent } \\
\text { accessible } \\
\text { area }\left(\AA^{2}\right)\end{array}$ & $\begin{array}{c}\mathrm{C}: \\
\mathrm{Hf} \text { in } \\
\mathrm{H}_{2} \mathrm{O} \\
\text { (kcal/ } \\
\text { mol) }\end{array}$ & $\begin{array}{c}\text { D: } \\
\text { Number } \\
\text { of } N \text { atom }\end{array}$ & $\begin{array}{c}E: \\
\text { Number } \\
\text { of } O \\
\text { atom }\end{array}$ & Clog \\
\hline D2339 & $\begin{array}{l}\text { HB Ac-Ala-GluH-L-AspH- } \\
\text { Val-NH }{ }_{2} \text { trans1 }\end{array}$ & -457.4 & 421.1 & -496.5 & 5 & 9 & -1.86 \\
\hline D2340 & $\begin{array}{l}\mathrm{HB} \text { Ac-Ala-GluH-D-AspH- } \\
\text { Val-NH } \mathrm{N}_{2} \text { trans1 }\end{array}$ & -457.1 & 414.0 & -495.8 & 5 & 9 & -2.01 \\
\hline D2341 & $\begin{array}{l}\text { HB Ac-Ala-GluH-L-AspH- } \\
\text { Val-NH }{ }_{2} \text { trans2 }\end{array}$ & -454.5 & 447.1 & -495.1 & 5 & 9 & -1.35 \\
\hline D2342 & $\begin{array}{l}\text { HB Ac-Ala-GluH-D-AspH- } \\
\text { Val-NH }{ }_{2} \text { trans } 2\end{array}$ & -443.8 & 422.6 & -494.0 & 5 & 9 & -2.18 \\
\hline D2343 & $\begin{array}{l}\text { HB Ac-Ala-GluH-L- } \\
\beta A s p H-V a l-\mathrm{NH}_{2} \text { trans1 }\end{array}$ & -453.0 & 414.1 & -494.7 & 5 & 9 & -2.10 \\
\hline D2344 & $\begin{array}{l}\text { HB Ac-Ala-GluH-D- } \\
\beta \text { AspH-Val-NH } \mathrm{N}_{2} \text { trans1 }\end{array}$ & -453.9 & 429.9 & -492.6 & 5 & 9 & -1.68 \\
\hline D2345 & $\begin{array}{l}\text { HB Ac-Ala-GluH-L- } \\
\beta \text { AspH-Val-NH } \mathrm{N}_{2} \text { trans2 }\end{array}$ & -449.2 & 420.2 & -490.6 & 5 & 9 & -1.97 \\
\hline D2346 & $\begin{array}{l}\text { HB Ac-Ala-GluH-D- } \\
\beta \text { AspH-Val- } \mathrm{NH}_{2} \text { trans2 }\end{array}$ & -452.0 & 418.4 & -490.3 & 5 & 9 & -1.92 \\
\hline KD2339 & $\begin{array}{l}\text { HB Ac-Ala-LysH-L-AspH- } \\
\text { Val-NH } \\
\text { trans1 }\end{array}$ & -373.5 & 453.3 & -426.1 & 6 & 7 & -0.87 \\
\hline KD2340 & $\begin{array}{l}\text { HB Ac-Ala-LysH-D-AspH- } \\
\text { Val-NH }{ }_{2} \text { trans1 }\end{array}$ & -368.5 & 466.5 & -424.4 & 6 & 7 & -0.70 \\
\hline KD2341 & $\begin{array}{l}\mathrm{HB} \text { Ac-Ala-LysH-L-AspH- } \\
\text { Val- } \mathrm{NH}_{2} \text { trans2 }\end{array}$ & -369.9 & 425.5 & -422.2 & 6 & 7 & -1.48 \\
\hline KD2342 & $\begin{array}{l}\text { HB Ac-Ala-LysH-D-AspH- } \\
\text { Val- } \mathrm{NH}_{2} \text { trans2 }\end{array}$ & -365.5 & 445.6 & -422.1 & 6 & 7 & -1.18 \\
\hline KD2343 & $\begin{array}{l}\text { HB Ac-Ala-LysH-L- } \\
\beta \text { AspH-Val- } \mathrm{NH}_{2} \text { trans1 }\end{array}$ & -371.9 & 442.1 & -424.3 & 6 & 7 & -1.12 \\
\hline KD2344 & $\begin{array}{l}\text { HB Ac-Ala-LysH-D- } \\
\beta \text { AspH-Val- } \mathrm{NH}_{2} \text { trans1 }\end{array}$ & -371.9 & 456.7 & -409.0 & 6 & 7 & -0.40 \\
\hline KD2345 & $\begin{array}{l}\text { HB Ac-Ala-LysH-L- } \\
\beta \text { AspH-Val-NH }{ }_{2} \text { trans2 }\end{array}$ & -365.3 & 454.7 & -411.2 & 6 & 7 & -0.70 \\
\hline KD2346 & $\begin{array}{l}\text { HB Ac-Ala-LysH-D- } \\
\beta \text { AspH-Val-NH } \mathrm{NH}_{2} \text { trans2 }\end{array}$ & -367.1 & 452.4 & -433.7 & 6 & 7 & -1.28 \\
\hline
\end{tabular}

Hf: Heat of formation; Clog P: Calculated log P.

HB: Calculation was carried out for the segmental models having a hydrogen bond between $\mathrm{C}=\mathrm{O}$ of Ala residue and $\mathrm{NH}$ of Val residue. GluH (Glutamic acid) and AspH (Aspartic acid) of which side chains protonated and liked with hydrogen bonding. LysH (Lysine) and AspH (Aspartic acid) of which side chains are protonated and linked with ionic bonding. All the amino acids without heading D- have L-chirality.

Heading only $\beta$ is $\beta$-carboxy of L-Asp making peptide bond with Ala residue.

Heading $D-\beta$ is $\beta$-carboxy of D-Asp making peptide bond with Ala residue. 


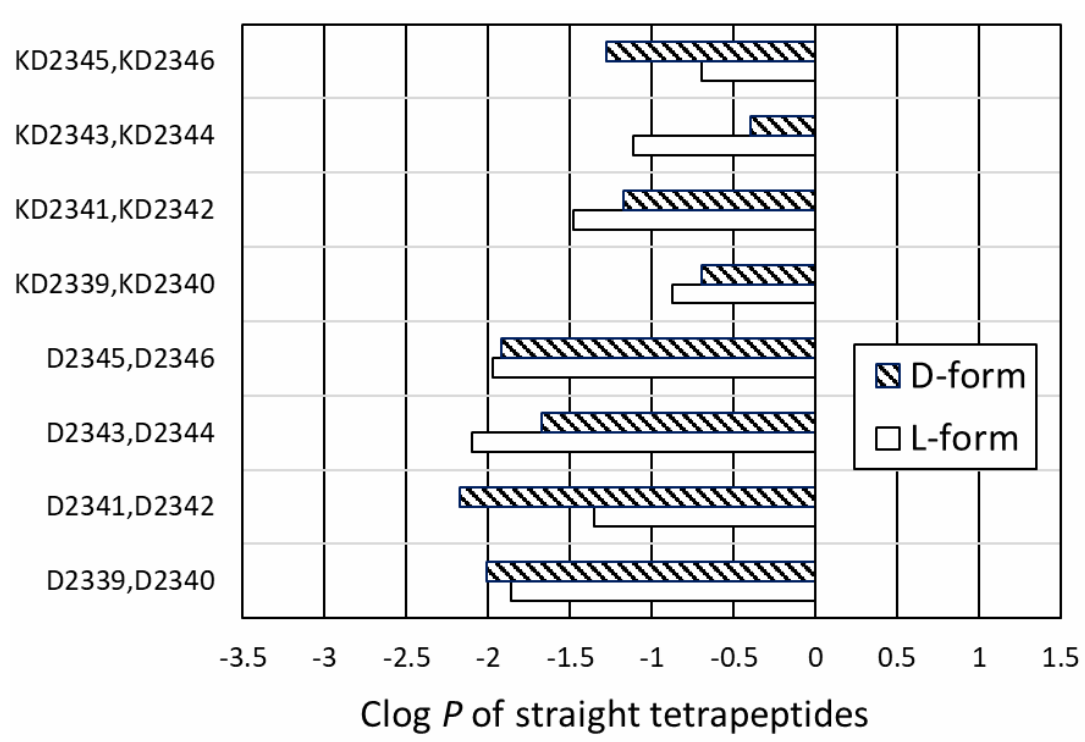

Figure 11. Clog $P$ values of the tetrapeptide models of $A c-A^{21}-E^{22}-D^{23}-V^{24}-N_{2}$ (the wild type) and $\mathrm{Ac}-\mathrm{A}^{21}-\mathrm{K}^{22}-\mathrm{D}^{23}-\mathrm{V}^{24}-\mathrm{NH}_{2}$ (Italian mutant) as well as comparing the L-epimer and D-epimer.

Table 9. Calculated $\log P$ values of tetrapeptide imides at $D^{23}$ in the wild and Italian mutant of Amyloid $\beta 42$.

\begin{tabular}{|c|c|c|c|c|c|c|c|}
\hline No. & $N$-Acetyl-Peptide amides & $\begin{array}{c}\text { A: } \\
\text { Hf in } \\
\text { vacuum } \\
\text { (kcal/ } \\
\text { mol) }\end{array}$ & $\begin{array}{c}\text { B: } \\
\text { Solvent } \\
\text { accessible } \\
\text { area }\left(\AA^{2}\right)\end{array}$ & $\begin{array}{c}\mathrm{C}: \\
\mathrm{Hf} \text { in } \\
\mathrm{H}_{2} \mathrm{O} \\
\text { (kcal/ } \\
\text { mol) }\end{array}$ & $\begin{array}{c}\text { D: } \\
\text { Number } \\
\text { of } N \\
\text { atom }\end{array}$ & $\begin{array}{c}E: \\
\text { Number } \\
\text { of } O \\
\text { atom }\end{array}$ & $\underset{\mathbf{P}}{\text { Clog }}$ \\
\hline D2347 & $\begin{array}{l}\text { Ac-Ala-GluH-L- } \\
\text { Aspimide } \alpha \mathrm{H}-\text { Val- } \mathrm{NH}_{2} \text { trans } 1\end{array}$ & -384.0 & 467.4 & -425.2 & 5 & 8 & -0.60 \\
\hline D2348 & $\begin{array}{l}\text { Ac-Ala-GluH-D- } \\
\text { Aspimide } \alpha \mathrm{H}-\text { Val- } \mathrm{NH}_{2} \text { trans1 }\end{array}$ & -392.0 & 429.2 & -432.2 & 5 & 8 & -1.36 \\
\hline D2349 & $\begin{array}{l}\text { Ac-Ala-GluH-L- } \\
\text { Aspimide } \alpha \mathrm{H}-\text { Val- } \mathrm{NH}_{2} \text { trans2 }\end{array}$ & -383.2 & 440.2 & -425.4 & 5 & 8 & -1.22 \\
\hline D2350 & $\begin{array}{l}\text { Ac-Ala-GluH-D- } \\
\text { Aspimide } \alpha \mathrm{H}-\text { Val- } \mathrm{NH}_{2} \text { trans2 }\end{array}$ & -388.0 & 428.3 & -422.0 & 5 & 8 & -1.24 \\
\hline D2351 & $\begin{array}{l}\text { Ac-Ala-GluH-L- } \\
\text { Aspimide } \beta \mathrm{H}-\mathrm{Val}-\mathrm{NH}_{2} \text { trans } 1\end{array}$ & -388.0 & 438.1 & -424.4 & 5 & 8 & -1.09 \\
\hline D2352 & $\begin{array}{l}\text { Ac-Ala-GluH-D- } \\
\text { Aspimide } \beta \mathrm{H}-\mathrm{V} \text { al- } \mathrm{NH}_{2} \text { trans } 1\end{array}$ & -384.1 & 451.1 & -427.4 & 5 & 8 & -1.01 \\
\hline D2353 & $\begin{array}{l}\text { Ac-Ala-GluH-L- } \\
\text { Aspimide } \beta H-V a l-\mathrm{NH}_{2} \text { trans } 2\end{array}$ & -381.7 & 470.6 & -432.6 & 5 & 8 & -0.80 \\
\hline D2354 & $\begin{array}{l}\text { Ac-Ala-GluH-D- } \\
\text { Aspimide } \beta \mathrm{H}-\mathrm{Val}-\mathrm{NH}_{2} \text { trans2 }\end{array}$ & -383.5 & 441.1 & -428.2 & 5 & 8 & -1.26 \\
\hline KD2347 & $\begin{array}{l}\text { Ac-Ala-LysH-L- } \\
\text { Aspimide } \alpha \mathrm{H}-\mathrm{Val}-\mathrm{NH}_{2} \text { trans1 }\end{array}$ & -177.1 & 473.5 & -257.0 & 6 & 6 & -1.24 \\
\hline KD2348 & $\begin{array}{l}\text { Ac-Ala-LysH-D- } \\
\text { Aspimide } \alpha \mathrm{H}-\mathrm{Val}-\mathrm{NH}_{2} \text { trans } 1\end{array}$ & -180.5 & 454.3 & -247.6 & 6 & 6 & -1.29 \\
\hline
\end{tabular}


Table 9 continued..

\begin{tabular}{|c|c|c|c|c|c|c|c|}
\hline No. & $N$-Acetyl-Peptide amides & $\begin{array}{c}\text { A: } \\
\text { Hf in } \\
\text { vacuum } \\
\text { (kcal/ } \\
\text { mol) }\end{array}$ & $\begin{array}{c}\text { B: } \\
\text { Solvent } \\
\text { accessible } \\
\text { area }\left(\AA^{2}\right)\end{array}$ & $\begin{array}{c}\mathrm{C}: \\
\mathrm{Hf} \text { in } \\
\mathrm{H}_{2} \mathrm{O} \\
\text { (kcal/ } \\
\text { mol) }\end{array}$ & $\begin{array}{c}\text { D: } \\
\text { Number } \\
\text { of } N \\
\text { atom }\end{array}$ & $\begin{array}{c}E: \\
\text { Number } \\
\text { of } O \\
\text { atom }\end{array}$ & Clog \\
\hline KD2349 & $\begin{array}{l}\text { Ac-Ala-LysH-L- } \\
\text { Aspimide } \alpha \mathrm{H}-\text { Val- } \mathrm{NH}_{2} \text { trans2 }\end{array}$ & -182.9 & 456.3 & -253.1 & 6 & 6 & -1.33 \\
\hline KD2350 & $\begin{array}{l}\text { Ac-Ala-LysH-D- } \\
\text { Aspimide } \alpha \mathrm{H}-\mathrm{Val}-\mathrm{NH}_{2} \text { trans2 }\end{array}$ & -171.5 & 462.6 & -253.5 & 6 & 6 & -1.55 \\
\hline KD2351 & $\begin{array}{l}\text { Ac-Ala-LysH-L- } \\
\text { Aspimide } \beta \mathrm{H}-\mathrm{V} \text { al- } \mathrm{NH}_{2} \text { trans } 1\end{array}$ & -180.3 & 467.7 & -254.0 & 6 & 6 & -1.18 \\
\hline KD2352 & $\begin{array}{l}\text { Ac-Ala-LysH-D- } \\
\text { Aspimide } \beta \mathrm{H}-\mathrm{V} \text { al- } \mathrm{NH}_{2} \text { trans1 }\end{array}$ & -170.6 & 453.6 & -232.1 & 6 & 6 & -1.20 \\
\hline KD2353 & $\begin{array}{l}\text { Ac-Ala-LysH-L- } \\
\text { Aspimide } \beta \mathrm{H}-\mathrm{Val}-\mathrm{NH}_{2} \text { trans2 }\end{array}$ & -167.4 & 471.9 & -249.1 & 6 & 6 & -1.35 \\
\hline KD2354 & $\begin{array}{l}\text { Ac-Ala-LysH-D- } \\
\text { Aspimide } \beta \mathrm{H}-\mathrm{Val}-\mathrm{NH}_{2} \text { trans } 2\end{array}$ & -157.9 & 445.6 & -245.0 & 6 & 6 & -2.10 \\
\hline
\end{tabular}

Hf: Heat of formation; Clog P: Calculated log P.

GluH (Glutamic acid) and AspH (Aspartic acid) of which side chains protonated and liked with hydrogen bonding. LysH (Lysine) and AspH (Aspartic acid) of which side chains are protonated and linked with ionic bonding. All the amino acids without heading D- have L-chirality. Aspimide $\alpha \mathrm{H}$ has an imide structure of which $\alpha$-carbonyl oxygen makes a bonding with the side chain of GluH or LysH.Aspimide $\beta \mathrm{H}$ has an imide structure of which $\beta$-carbonyl oxygen makes a bonding with the side chain of GluH or LysH.

Heading only $\beta$ is $\beta$-carboxy of L-Asp making peptide bond with Ala residue.

Heading $\mathrm{D}-\beta$ is $\beta$-carboxy of D-Asp making peptide bond with Ala residue.

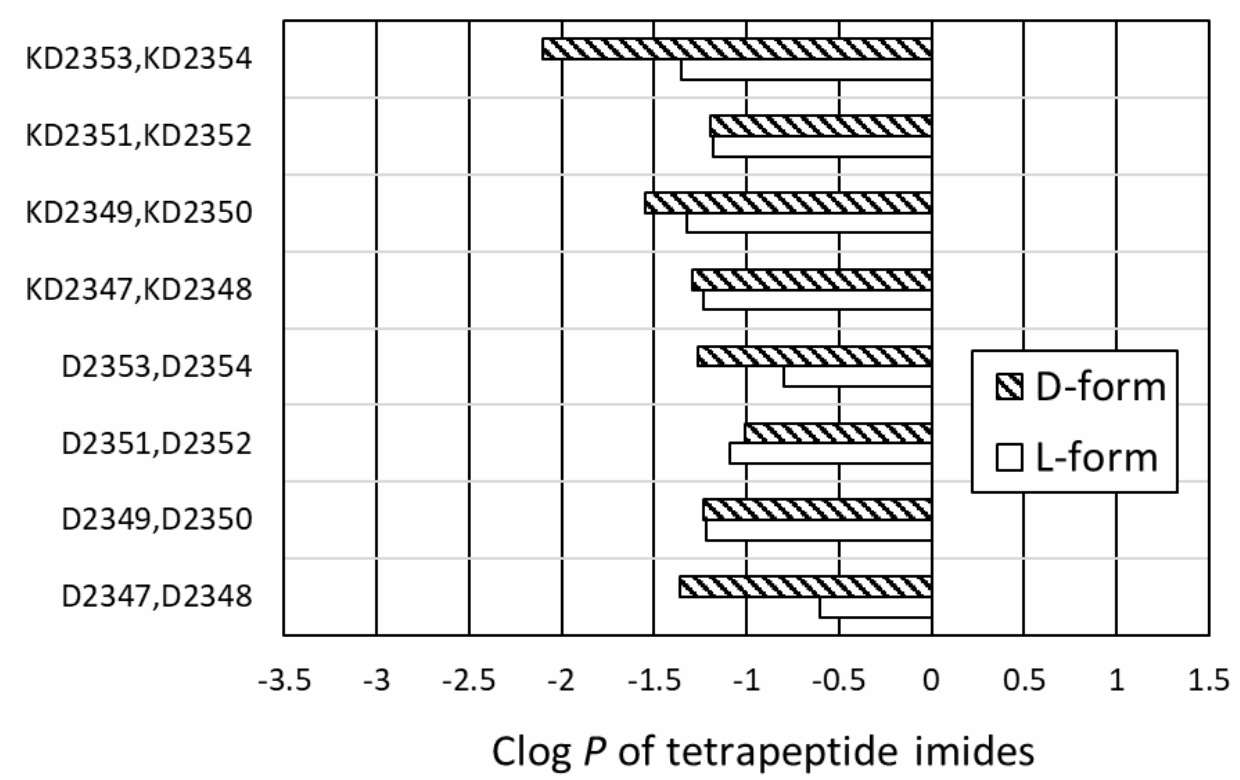

Figure 12. Clog $P$ values of the tetrapeptide imide models of $A c-\mathrm{A}^{21}-\mathrm{E}^{22}-\mathrm{D}^{23}-\mathrm{V}^{24}-\mathrm{NH}_{2}$ (the wild type) and Ac- $\mathrm{A}^{21}-\mathrm{K}^{22}-\mathrm{D}^{23}-\mathrm{V}^{24}-\mathrm{NH}_{2}$ (Italian mutant) as well as comparing the L-epimer and D-epimer. 
(1) $D^{23}:$ L-form, trans 1, $\alpha$-peptide

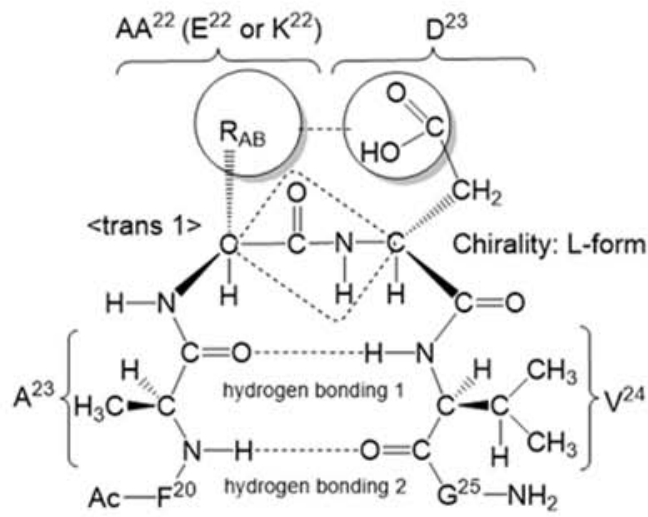

(3) $D^{23}:$ L-form, trans 1, $\beta$-peptide

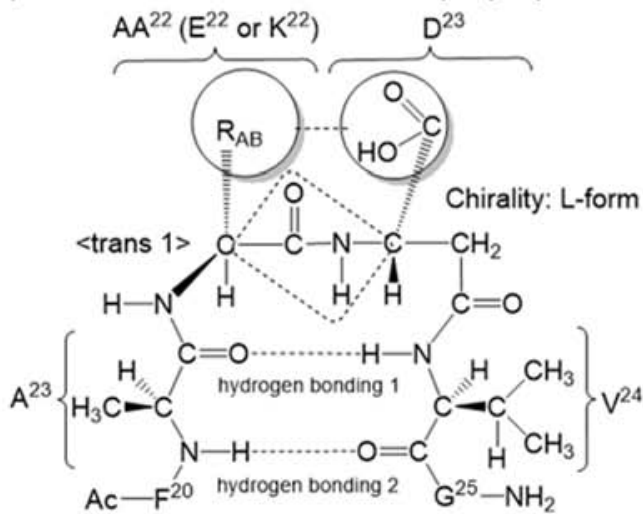

(2) $D^{23}$ : D-form, trans 1, $\alpha$-peptide

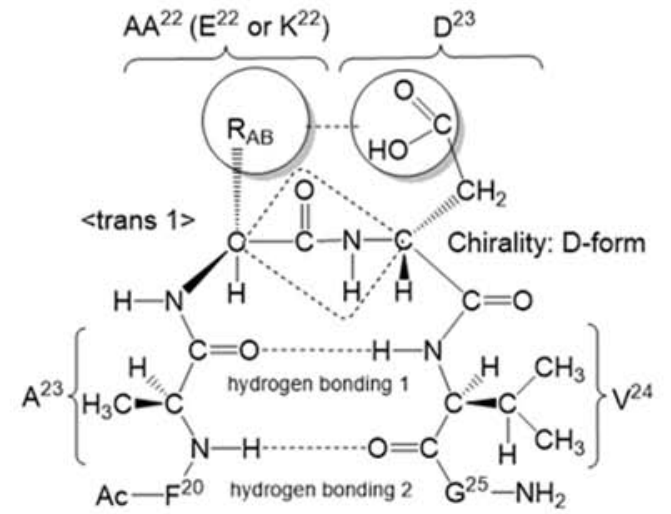

(4) $D^{23}$ : D-form, trans 1, $\beta$-peptide

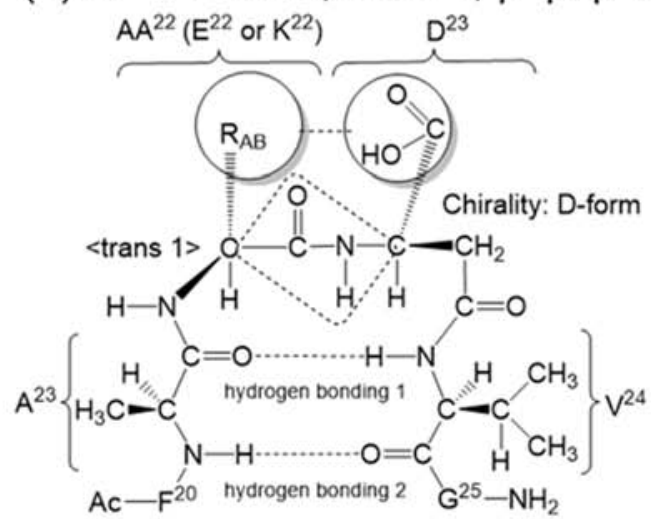

\section{Structure of trans 2}

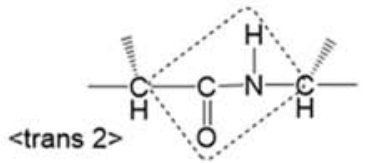

Interaction between side chains of $E^{22}$ and $D^{23}$ or $K^{22}$ and $D^{23}$
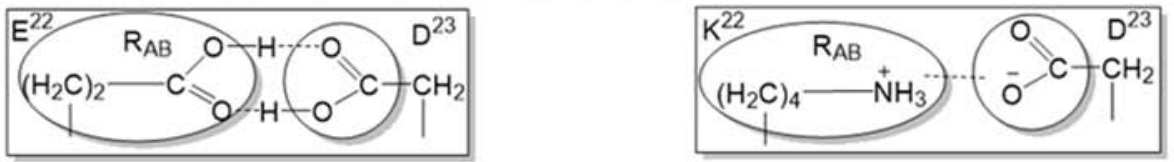

Figure 13. Chemical structures of the segmental hexapeptides of Amyloid $\beta 42$ wild type and Italian mutant epimers having L-Asp or D-Asp at $\mathrm{D}^{23}$.

In the case where $\mathrm{AA}^{22}$ is $\mathrm{E}^{22}$, the interaction is hydrogen bonding between two carboxy groups. In the case where $\mathrm{AA}^{22}$ is $\mathrm{K}^{23}$, the interaction is ionic bonding between ammonium and carboxylate ions.

Table 10 and Figure 14 show data for the straight hexapeptide of the wild type and Italian mutant of Amyloid $\beta 42$. Comparing Clog $P$ values of the wild type (D2355 to D2362) with those of the
Italian mutant (KD2355 to KD2362), the higher hydrophobicity can be seen in the Italian mutant KD2355 to KD2362 (0.62 to 1.48 ) than in the models D2355 to D2362 ( -0.89 to -0.13$)$ in the wild type. Most of the D-epimers (( -0.52 to -0.13$)$ and (0.71 to 1.48)) have higher Clog $P$ values than those of the L-epimers (( -0.48 to -0.89$)$ and $(0.62$ to 1.01)) of the wild type and Italian mutant, respectively. 
Table 10. Calculated $\log P$ values of hexapeptides isomerized at $\mathrm{D}^{23}$ in the wild and Italian mutant of Amyloid $\beta 42$ in case of possessing one hydrogen bond between $\mathrm{A}^{21}$ and $\mathrm{V}^{24}$.

\begin{tabular}{|c|c|c|c|c|c|c|c|}
\hline No. & $N$-Acetyl-Peptide amides & $\begin{array}{c}\text { A: } \\
\text { Hf in } \\
\text { vacuum } \\
\text { (kcal/mol) }\end{array}$ & $\begin{array}{l}\text { B: Solvent } \\
\text { accessible } \\
\text { area }\left(\AA^{2}\right)\end{array}$ & $\begin{array}{c}\mathrm{C}: \\
\mathrm{Hf} \text { in } \\
\mathrm{H}_{2} \mathrm{O} \\
\text { (kcal/ } \\
\text { mol) }\end{array}$ & $\begin{array}{c}\text { D: } \\
\text { Number } \\
\text { of } \mathbf{N} \\
\text { atom }\end{array}$ & $\begin{array}{c}\text { E: } \\
\text { Number } \\
\text { of } O \\
\text { atom }\end{array}$ & $\begin{array}{c}\text { Clog } \\
\mathbf{P}\end{array}$ \\
\hline D2355 & $\begin{array}{l}\text { HB Ac-FAEDVG-NH }{ }_{2} \\
\text { trans1 }\end{array}$ & -522.6 & 551.8 & -564.0 & 7 & 11 & -0.50 \\
\hline D2356 & $\begin{array}{l}\mathrm{HB} \text { Ac-FAE(D)DVG-NH } \\
\text { trans1 }\end{array}$ & -527.9 & 554.4 & -561.9 & 7 & 11 & -0.23 \\
\hline D2357 & $\begin{array}{l}\text { HB Ac-FAEDVG-NH }{ }_{2} \\
\text { trans2 }\end{array}$ & -523.5 & 557.1 & -572.6 & 7 & 11 & -0.59 \\
\hline D2358 & $\begin{array}{l}\text { HB Ac-FAE(D)DVG-NH }{ }_{2} \\
\text { trans2 }\end{array}$ & -523.9 & 572.4 & -568.1 & 7 & 11 & -0.13 \\
\hline D2359 & $\begin{array}{l}\mathrm{HB} \text { Ac-FAED }(\beta) \mathrm{VG}^{-\mathrm{NH}_{2}} \\
\text { trans1 }\end{array}$ & -527.3 & 543.4 & -561.7 & 7 & 11 & -0.48 \\
\hline D2360 & $\begin{array}{l}\text { HB Ac-FAE(D)D( } \beta) \text { VG- } \\
\mathrm{NH}_{2} \text { trans1 }\end{array}$ & -525.2 & 560.5 & -563.4 & 7 & 11 & -0.22 \\
\hline D2361 & $\begin{array}{l}\mathrm{HB} \text { Ac-FAED }(\beta) \text { VG-NH } \\
\text { trans2 }\end{array}$ & -517.6 & 536.4 & -560.6 & 7 & 11 & -0.89 \\
\hline D2362 & $\begin{array}{l}\mathrm{HB} \text { Ac-FAE(D)D( } \beta) \mathrm{VG}- \\
\mathrm{NH}_{2} \text { trans2 }\end{array}$ & -519.6 & 553.0 & -562.4 & 7 & 11 & -0.52 \\
\hline KD2355 & $\begin{array}{l}\text { HB Ac-FAKDVG-NH }{ }_{2} \\
\text { trans1 }\end{array}$ & -432.6 & 611.7 & -496.2 & 8 & 9 & 0.74 \\
\hline KD2356 & $\begin{array}{l}\text { HB Ac-FAK(D)DVG- } \\
\mathrm{NH}_{2} \text { trans1 }\end{array}$ & -430.5 & 623.0 & -494.7 & 8 & 9 & 0.96 \\
\hline KD2357 & $\begin{array}{l}\text { HB Ac-FAKDVG-NH }{ }_{2} \\
\text { trans2 }\end{array}$ & -436.8 & 602.9 & -498.2 & 8 & 9 & 0.62 \\
\hline KD2358 & $\begin{array}{l}\text { HB Ac-FAK(D)DVG- } \\
\mathrm{NH}_{2} \text { trans2 }\end{array}$ & -432.7 & 639.9 & -491.2 & 8 & 9 & 1.48 \\
\hline KD2359 & $\begin{array}{l}\mathrm{HB} \text { Ac-FAKD }(\beta) \mathrm{VG}-\mathrm{NH}_{2} \\
\text { trans1 }\end{array}$ & -427.2 & 657.6 & -516.9 & 8 & 9 & 1.01 \\
\hline KD2360 & $\begin{array}{l}\text { HB Ac-FAK(D)D( } \beta) \text { VG- } \\
\mathrm{NH}_{2} \text { trans1 }\end{array}$ & -417.7 & 607.7 & -477.0 & 8 & 9 & 0.71 \\
\hline KD2361 & $\begin{array}{l}\text { HB Ac-FAKD }(\beta) \text { VG- } \mathrm{NH}_{2} \\
\text { trans2 }\end{array}$ & -442.2 & 596.1 & -497.7 & 8 & 9 & 0.65 \\
\hline KD2362 & $\begin{array}{l}\text { HB Ac-FAK(D)D }(\beta) \text { VG- } \\
\mathrm{NH}_{2} \text { trans2 }\end{array}$ & -444.3 & 633.2 & -510.9 & 8 & 9 & 1.17 \\
\hline
\end{tabular}

Hf: Heat of formation; Clog P: Calculated log P.

HB: one hydrogen bond in the $\beta$-sheet structure.

$\mathrm{E}$ (Glutamic acid) and D (Aspartic acid) of which side chains protonated and liked with hydrogen bonding. $\mathrm{K}$ (Lysine) and $\mathrm{D}$ (Aspartic acid) of which side chains are protonated and linked with ionic bonding. All the amino acids without heading (D) have L-chirality. (D)D: D-Asp; D( $\beta$ ): L- $\beta$ Asp; (D)D( $\beta$ ): D- $\beta$ Asp. 


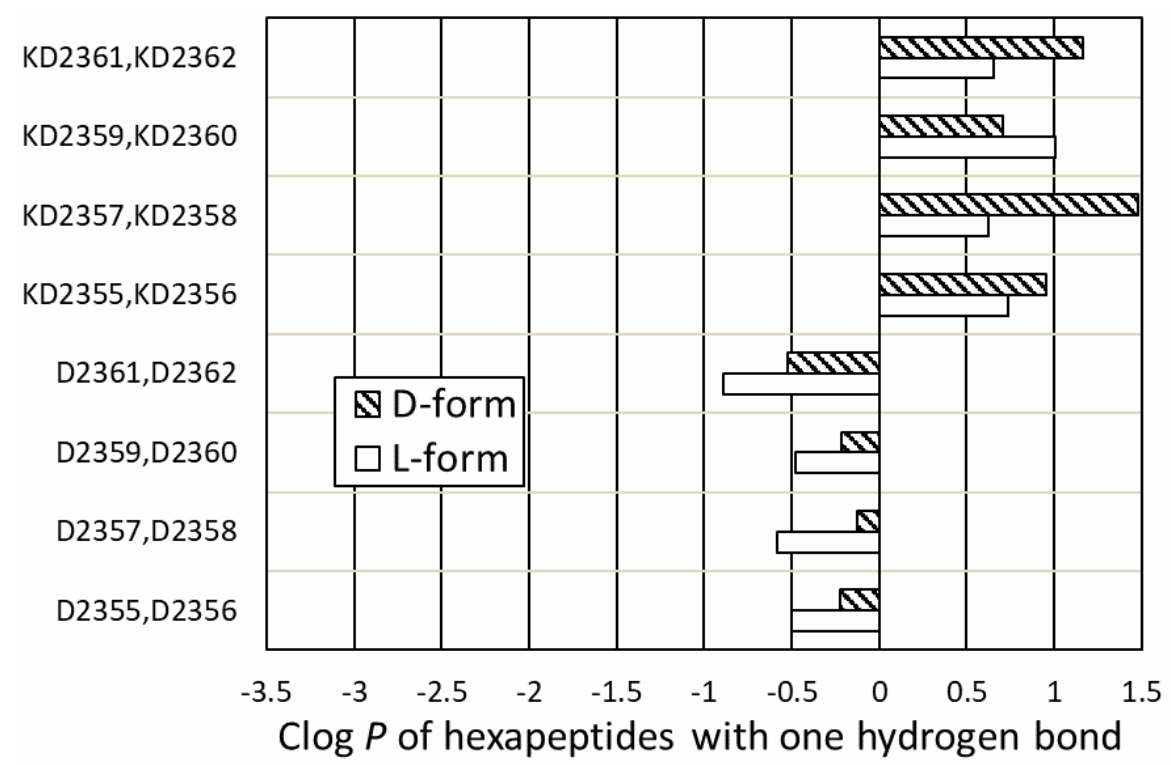

Figure 14. Clog $P$ values of the hexapeptide models of $A c-F^{20}-A^{21}-E^{22}-D^{23}-V^{24}-G^{25}-N_{2}$ (the wild type) and $\mathrm{Ac}-\mathrm{F}^{20}-\mathrm{A}^{21}-\mathrm{K}^{22}-\mathrm{D}^{23}-\mathrm{V}^{24}-\mathrm{G}^{25}-\mathrm{NH}_{2}$ (Italian mutant) as well as comparing the L-epimer and D-epimer.

Table 11 and Figure 15 show data for the hexapeptide models of the wild type and Italian mutant of Amyloid 342 . Comparing Clog $P$ values of the wild type (D2363 to D2370) with those of the Italian mutant (KD2363 to KD2370), a little larger hydrophobicity can be seen in the models D2363 to D2370 ( -0.70 to 0.05$)$ in the wild type than in the Italian mutant KD2363 to KD2370 (0.32 to 1.32).

Most of the D-epimers ( $(-0.23$ to 0.04$)$ and $(0.35$ to 1.32)) have higher Clog $P$ values than those of the L-epimers (( -0.70 to 0.05$)$ and (0.32 to 0.92$))$ of the wild type and Italian mutant, respectively.

\subsection{Comparing $C \log P$ values of the segmental peptide models of the wild type with those of the Italian mutant from the viewpoint of the number of sequences}

Figure 16 summarizes the calculation results of Clog $P$ values of the segmental peptide models for the wild type. The data are shown as three columns that give minimum, average, and maximum calculation results for the segmental peptides. For example, D232-2311 (L5) means five models (having hydrogen bonding or not between side chains, trans 1 or trans 2, $\alpha$-peptide or $\beta$-peptide) possessing L-chirality in the segmental peptides D232 to D2311, and D2314-
2322 (D5) means five models possessing imide structures and D-chirality in the segmental peptides D2314 to D2322. These models are dipeptides. The columns positioned in the area separated by dashed lines show the data for models for dipeptides, tripeptides, tetrapeptides, and hexapeptides.

Clog $P$ values of the models increased slightly with the larger peptides. Comparing the $C \log P$ values of the models having the same amino acid numbers, the values for the straight peptide models were usually larger than those for the imide models. Compared with the results of L-epimer and D-epimer having the same peptide size, a similar Clog $P$ value was observed in most sizes of peptides except for hexapeptides, which showed larger $C \log P$ values in D-epimers than in L-epimers. These results suggest that the epimerization at $D^{23}$ in the hexapeptides or longer segmental peptides would facilitate further hydrophobicity to reach aggregation.

Figure 17 summarizes the calculation results of Clog $P$ values of the segmental peptide models of the Italian mutant. In the same way as Figure 16, the data are shown as three columns that contain minimum, average, and maximum of the calculation results for the segmental peptides. 
Table 11. Calculated $\log P$ values of hexapeptides isomerized at $\mathrm{D}^{23}$ in the wild and Italian mutant of Amyloid $\beta 42$ in case of possessing two hydrogen bonds between $\mathrm{A}^{21}$ and $\mathrm{V}^{24}$.

\begin{tabular}{|c|c|c|c|c|c|c|c|}
\hline No. & $N$-Acetyl-Peptide amides & $\begin{array}{c}\text { A: } \\
\text { Hf in } \\
\text { vacuum } \\
\text { (kcal/ } \\
\text { mol) }\end{array}$ & $\begin{array}{c}\text { B: } \\
\text { Solvent } \\
\text { accessible } \\
\text { area }\left(\AA^{2}\right)\end{array}$ & $\begin{array}{c}\mathrm{C}: \\
\mathrm{Hf} \text { in } \\
\mathrm{H}_{2} \mathrm{O} \\
\text { (kcal/ } \\
\text { mol) }\end{array}$ & $\begin{array}{c}\text { D: } \\
\text { Number } \\
\text { of } \mathbf{N} \\
\text { atom }\end{array}$ & $\begin{array}{c}\text { E: } \\
\text { Number } \\
\text { of } O \\
\text { atom }\end{array}$ & $\begin{array}{c}\text { Clog } \\
\mathbf{P}\end{array}$ \\
\hline D2363 & $\begin{array}{l}\text { 2HB Ac-FAEDVG-NH } \\
\text { trans1 }\end{array}$ & -521.9 & 551.6 & -558.8 & 7 & 11 & -0.41 \\
\hline D2364 & $\begin{array}{l}2 \mathrm{HB} \text { Ac-FAE(D)DVG-NH} \\
\text { trans1 }\end{array}$ & -524.3 & 541.9 & -565.2 & 7 & 11 & -0.12 \\
\hline D2365 & $\begin{array}{l}\text { 2HB Ac-FAEDVG-NH } \\
\text { trans } 2\end{array}$ & -522.7 & 571.1 & -559.0 & 7 & 11 & 0.05 \\
\hline D2366 & $\begin{array}{l}2 \mathrm{HB} \text { Ac-FAE(D)DVG-NH} \\
\text { trans2 }\end{array}$ & -524.4 & 560.2 & -562.8 & 7 & 11 & -0.23 \\
\hline D2367 & $\begin{array}{l}2 \mathrm{HB} \text { Ac-FAED }(\beta) \mathrm{VG}-\mathrm{NH}_{2} \\
\text { trans1 }\end{array}$ & -527.1 & 548.3 & -557.6 & 7 & 11 & -0.27 \\
\hline D2368 & $\begin{array}{l}2 \mathrm{HB} \text { Ac-FAE }(\mathrm{D}) \mathrm{D}(\beta) \mathrm{VG}- \\
\mathrm{NH}_{2} \text { trans1 }\end{array}$ & -522.3 & 577.7 & -564.5 & 7 & 11 & 0.04 \\
\hline D2369 & $\begin{array}{l}2 \mathrm{HB} \text { Ac-FAED }(\beta) \mathrm{VG}-\mathrm{NH}_{2} \\
\text { trans } 2\end{array}$ & -517.5 & 550.4 & -564.6 & 7 & 11 & -0.70 \\
\hline D2370 & $\begin{array}{l}2 \mathrm{HB} \text { Ac-FAE }(\mathrm{D}) \mathrm{D}(\beta) \mathrm{VG}- \\
\mathrm{NH}_{2} \text { trans } 2\end{array}$ & -522.9 & 565.6 & -559.9 & 7 & 11 & -0.09 \\
\hline KD2363 & $\begin{array}{l}\text { 2HB Ac-FAKDVG-NH } \\
\text { trans1 }\end{array}$ & -437.1 & 606.4 & -502.6 & 8 & 9 & 0.32 \\
\hline KD2364 & $\begin{array}{l}\text { 2HB Ac-FAK(D)DVG- } \\
\mathrm{NH}_{2} \text { trans1 }\end{array}$ & -441.0 & 622.0 & -492.2 & 8 & 9 & 1.32 \\
\hline KD2365 & $\begin{array}{l}2 \mathrm{HB} \text { Ac-FAKDVG-NH} \\
\text { trans2 }\end{array}$ & -438.6 & 594.6 & -499.0 & 8 & 9 & 0.48 \\
\hline KD2366 & $\begin{array}{l}2 \mathrm{HB} \text { Ac-FAK(D)DVG- } \\
\mathrm{NH}_{2} \text { trans2 }\end{array}$ & -438.1 & 633.0 & -508.4 & 8 & 9 & 1.04 \\
\hline KD2367 & $\begin{array}{l}2 \mathrm{HB} \text { Ac-FAKD }(\beta) \mathrm{VG}-\mathrm{NH}_{2} \\
\text { trans1 }\end{array}$ & -426.9 & 641.9 & -507.2 & 8 & 9 & 0.92 \\
\hline KD2368 & $\begin{array}{l}2 \mathrm{HB} \text { Ac-FAK }(\mathrm{D}) \mathrm{D}(\beta) \mathrm{VG}- \\
\mathrm{NH}_{2} \text { trans1 }\end{array}$ & -426.5 & 595.7 & -488.3 & 8 & 9 & 0.42 \\
\hline KD2369 & $\begin{array}{l}2 \mathrm{HB} \text { Ac-FAKD }(\beta) \mathrm{VG}-\mathrm{NH}_{2} \\
\text { trans2 }\end{array}$ & -422.9 & 621.8 & -507.8 & 8 & 9 & 0.35 \\
\hline KD2370 & $\begin{array}{l}2 \mathrm{HB} \text { Ac-FAK }(\mathrm{D}) \mathrm{D}(\beta) \mathrm{VG}- \\
\mathrm{NH}_{2} \text { trans2 }\end{array}$ & -431.9 & 598.3 & -485.5 & 8 & 9 & 0.71 \\
\hline
\end{tabular}

Hf: Heat of formation; Clog P: Calculated log P.

2HB: two hydrogen bonds in the $\beta$-sheet structure.

E (Glutamic acid) and D (Aspartic acid) of which side chains protonated and liked with hydrogen bonding. $\mathrm{K}$ (Lysine) and D (Aspartic acid) of which side chains are protonated and linked with ionic bonding.

All the amino acids without heading (D) have L-chirality. (D)D: D-Asp; $D(\beta)$ : L- $\beta$ Asp; (D)D( $\beta$ ): D- $\beta$ Asp. 


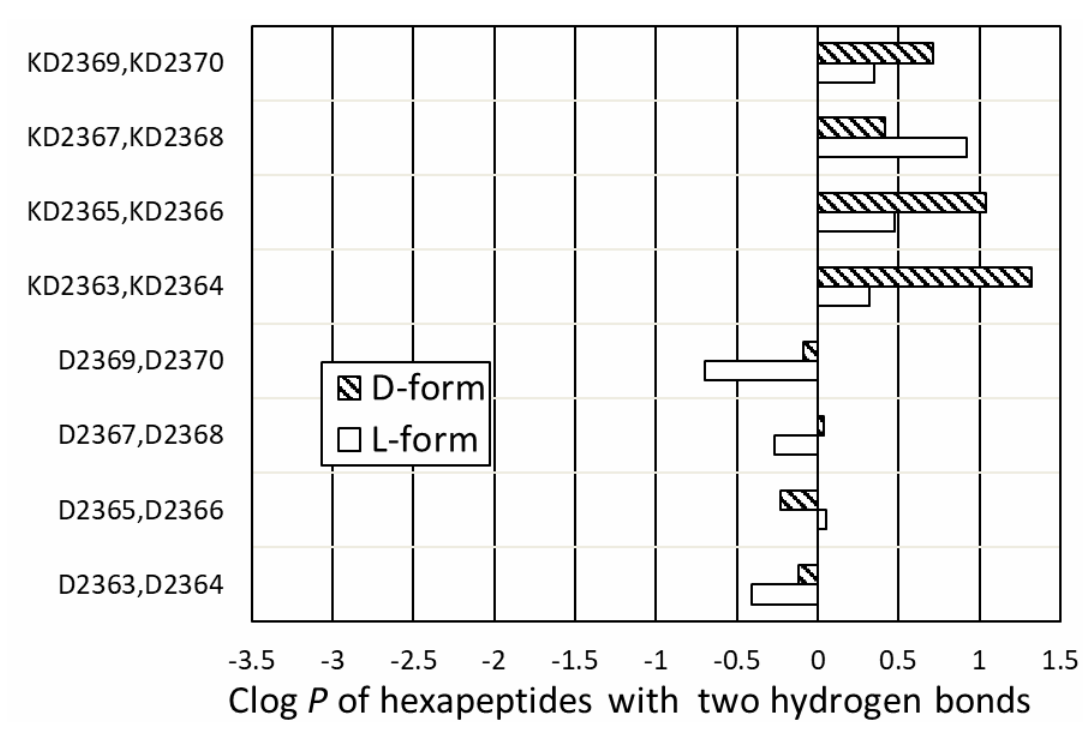

Figure 15. Clog $P$ values of the two hydrogen-bonding models of hexapeptide of $\mathrm{Ac}-\mathrm{F}^{20}-\mathrm{A}^{21}$ $\mathrm{E}^{22}-\mathrm{D}^{23}-\mathrm{V}^{24}-\mathrm{G}^{25}-\mathrm{NH}_{2}$ (the wild type) and $\mathrm{Ac}-\mathrm{F}^{20}-\mathrm{A}^{21}-\mathrm{K}^{22}-\mathrm{D}^{23}-\mathrm{V}^{24}-\mathrm{G}^{25}-\mathrm{NH}_{2}$ (Italian mutant) as well as comparing the L-epimer and D-epimer.

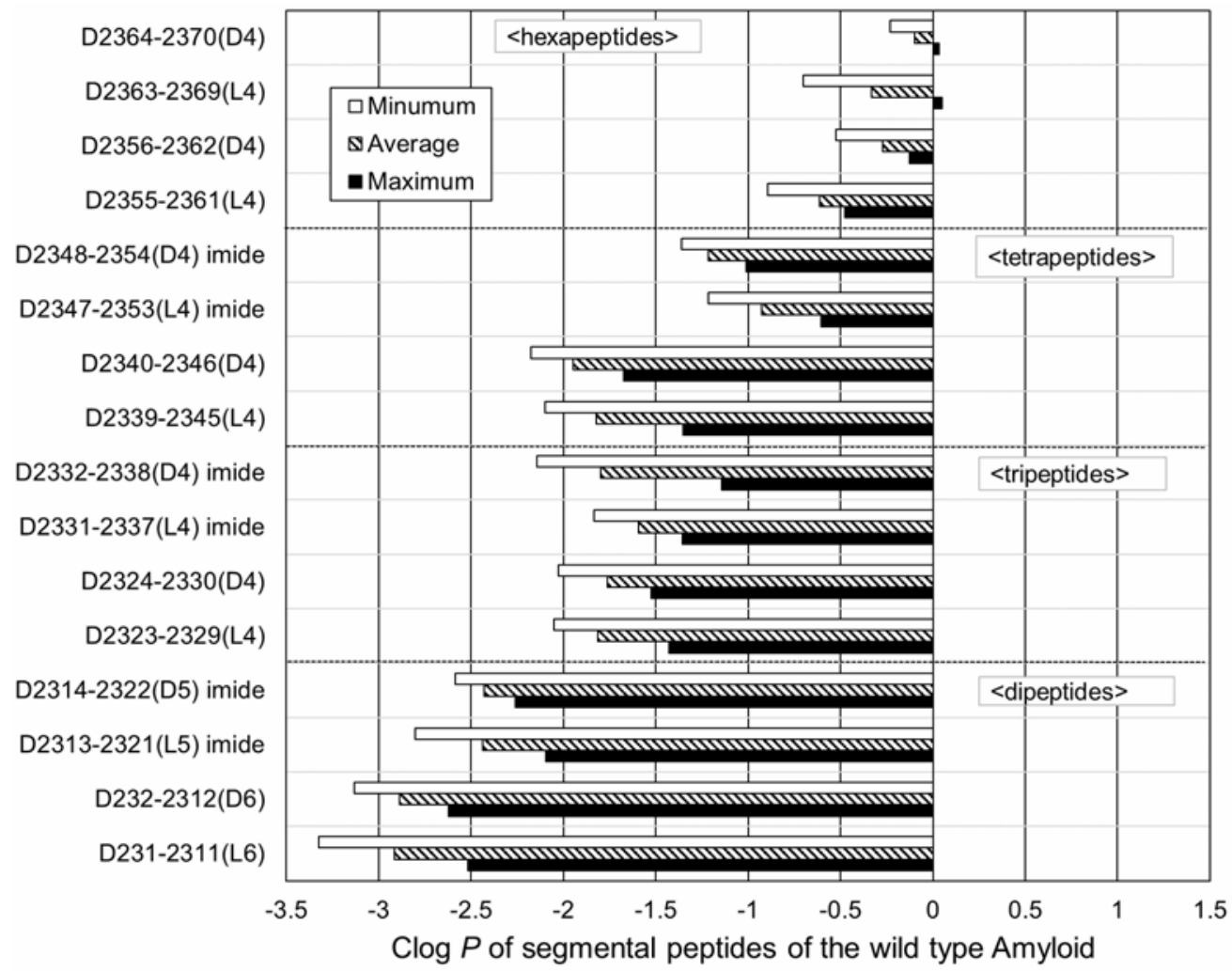

Figure 16. Clog $P$ values of the segmental peptides of the wild type of Amyloid $\beta 42$.

The three grouped columns present the data for minimum, average, and maximum Clog $P$ values according to each categorized chemical structure. For instance, D2323-2329 (L4) are composed of four L-epimer tripeptide structures: D2323, D2325, D2327, and D2329. 


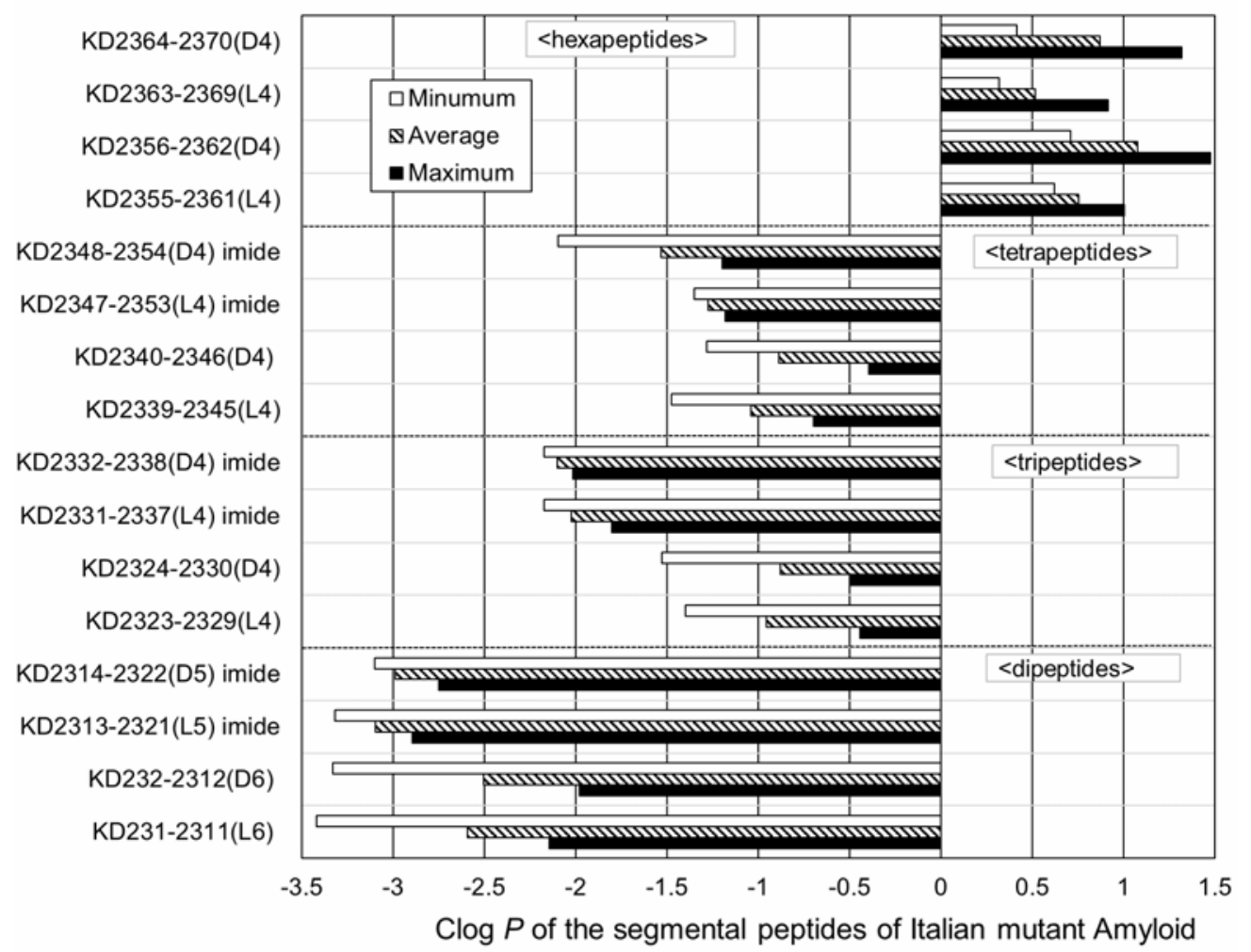

Figure 17. Clog $P$ values of the segmental peptides of the Italian mutant of Amyloid $\beta 42$.

The three grouped columns present the data for minimum, average, and maximum Clog $P$ values according to each categorized chemical structure. For instance, KD232-2312 (D6) are composed of six D-epimer dipeptide structures: KD232, KD234, KD236, KD238, KD2310, and KD2312.

However, Figure 17 shows the data for the Italian mutant segmental models numbered KD231-2311 (L6) and KD232-2312 (D6). Naming of the segmental models and arranging the data in Figure 17 are presented similarly to those in Figure 16.

Comparing the straight structure of the peptides, Clog $P$ values of the models increased slightly for the larger peptides. Although the Clog $P$ value of imides also increased with the larger ones, $C \log P$ values of the straight models were larger than those of imide models.

The results reveal that the imides of the wild type are more hydrophobic than their straight peptides, but the straight peptides of the Italian mutant are more hydrophobic than the imide models. Clog $P$ values of the L-epimer and D-epimer are similar when compared to $C \log P$ values of the same size of peptides: dipeptides, tripeptides, or tetrapeptides. However, in the data of tetrapeptide models, larger Clog $P$ values were obtained in the
D-epimer rather than in the L-epimer. All the results in hexapeptide models of the Italian mutant gave positive and much higher values than those in the hexapeptide models of the wild type as shown in Figure 16.

The calculation results demonstrate that if the epimerization occurred at the $\mathrm{D}^{23}$ position of the wild-type Amyloid $\beta 42$ from $L$ to D, the segmental hexapeptide area before and after $D^{23}$ must be more hydrophobic. If the epimerization occurred at the $\mathrm{D}^{23}$ position of the Italian mutant from $\mathrm{L}$ to $\mathrm{D}$, the same area before and after $\mathrm{D}^{23}$ must also be more hydrophobic. The resulting hydrophobicity $(0.5<\operatorname{Clog} P<1)$ of the epimerized segments of the Italian mutant must be much higher than those $(-0.7<\operatorname{Clog} P<0)$ of the wild type. Such results suggest that epimerization at $D^{23}$ in the wild type and Italian mutant Amyloid $\beta 42$ would make these more hydrophobic and would lead to more aggregation features. 


\section{CONCLUSIONS}

A linear relationship $\left(R^{2}=0.978\right)$ between Exptl. $\log P$ (logarithm of partition coefficient of octanol in water) and Clog $P$ values for amino acids and $N$-acetyl-peptide amides was obtained by a semiempirical method using PM5 for estimating the hydrophobicity of the segmental peptide models of Amyloid $\beta 42$.

It was suggested by the $C \log P$ calculation that epimerization at $\mathrm{D}^{1}$ and $\mathrm{D}^{7}$ as the common residues with the wild type and Italian mutant of Amyloid $\beta 42$ will make the original L-peptides more hydrophilic.

Clog $P$ values for the segmental models ( $N$-acetylpeptide- $\mathrm{NH}_{2}$ ) of dipeptides, tripeptides, tetrapeptides, and hexapeptides around the bending position at $\mathrm{D}^{23}$ were calculated. Clog $P$ values became larger with the larger peptides except for the imide structures.

Clog $P$ values for the straight segment peptides of the Italian mutant were larger than those of the wild type of Amyloid $\beta 42$. The results may correspond to the higher aggregation of the whole structure of the Italian mutant than the wild type of Amyloid $\beta 42$ because the higher hydrophobicity at the bending area may make the whole structure more hydrophobic.

Segmental hexapeptide models based on the $\mathrm{K}^{22}$ $D^{23}$ salt bridge and epimerization at the $D^{23}$ residue gave larger $\operatorname{Clog} P$ values than those of L-hexapeptides. The results suggested that the Italian mutant will be more hydrophobic than the original one if epimerization occurred at $\mathrm{D}^{23}$.

\section{CONFLICT OF INTEREST STATEMENT}

The author has no conflicts of interest directly relevant to the content of this article.

\section{REFERENCES}

1. Dyakin, V. V., Wisniewski, T. M. and Lajtha, A. 2021, Symmetry, 13, 455.

2. Yoshimura, T., Nishikawa, T. and Homma, H. 2016, "D-Amino Acids Physiology, Metabolism, and Application”, Springer Japan.

3. Konno, R., Brückner, H., D’Aniello, A., Fisher, G. and Fujii, N. 2009, "D-Amino
Acids: Practical Methods and Protocols: Damino Acids in Peptides and Proteins", Nova Science Publishers Inc., Hauppauge, NY.

4. Konno, R., Brückner, H., D’Aniello, A., Fisher, G., Fujii, N. and Homma, H. 2007, "D-Amino Acids: A New Frontier in Amino Acid and Protein Research-Practical Methods and Protocols", Nova Science Publishers Inc., Hauppauge, NY.

5. Montecucchi, P. C., Castiglione, R., Piani, S., Gonzzini, L. and Erspamer, V. 1981, Int. J. Pept. Prot. Res., 17, 275.

6. Broccardo, M., Erspamer, V., Erspamer, F. G., Improta, G., Linari, G., Melchiorri, P. and Montecucchi, P. C. 1981, Br. J. Pharmacol., 73, 625.

7. Fisher, H., Garcia, N. M., Payan, I. L., Cadilla-Perezrois, R., Sheremata, W. A. and Man, E. H. 1986, Biochem. Biophys. Res. Commun., 135, 683.

8. Richter, K., Egger, R. and Kreil, G. 1987, Science, 238, 200.

9. Erspamer, V., Melchiorri, P., FalconieriErspamer, G., Negri, L., Corsi, R., Severini, C., Barra, D., Simmaco, M. and Kreil, G. 1989, Proc. Natl. Acad. Sci. USA, 86, 5188.

10. Kamatani, Y., Minakata, H., Kenney, P. T., Iwashita, T., Watanabe, K., Funase, K., Sun, X. P., Yongsiri, A., Kim, K. H., Novales-Li, P., Novales, E. T., Kanapi, C. G., Takeuchi, H. and Nomoto, K. 1989, Biochem. Biophys. Res. Commun., 160, 1015.

11. Jolles, P. 1998, "D-Amino Acid in Sequences of Secreted Peptides of Multicellular Organisms”, Birkhauser Verlag, Basel.

12. Kumada, M., Teramoto, T., Kumagaye, K., Nakajima, K., Watanabe, T., Kawai, T., Kawakami, Y., Niidome, T., Sawada, K. and Nishizawa, Y. 1994, Mol. Pharmacol., 46, 587.

13. Heck, S. D., Siok, C. J., Krapcho, K. J., Kelbaugh, P. R., Thadeio, P. F., Welch, M. J., Williams, R. D., Ganong, A. H., Kelly, M. E., Lanzetti, A. J., William, R. G., Phillips, D., Parks, T. N., Jackson, H., Ahlijanian, M. K., Saccomano, N. A. and Volkmann, R. A. 1994, Science, 266, 1065. 
14. Masuda, W., Nouso, C., Kitamura, C., Terashita, M. and Noguchi, T. 2002, Arch. Oral. Biol., 47, 757.

15. Cloos, P. A. and Fledelius, C. 2000, Biochem. J., 345, 473.

16. Powell, J. T., Vine, N. and Grossman, M. 1992, Atherosclerosis, 97, 201.

17. Rocher, A. E., Lowenson, J. D., Clarke, S., Walkow, C., Wang, R., Cotter, R. J., Reardon, I. M., Zurcher-Neely, H. A., Heinrikson, R. L., Ball, M. J. and Greenberg, B. D. 1993, J. Biol. Chem., 268, 3072.

18. Masters, P. M., Bada, J. L. and Zigler, J. S. J. 1977, Nature, 268, 71.

19. Momose, Y., Fujii, N., Kodama, T., Tamagaki, Y., Nakanishi, H. and Kodama, M. 1998, Viva Origino, 26, 329.

20. Fujii, N. and Saito, T. 2004, Chem. Record, 4, 267.

21. Fujii, N., Tajima, S., Tanaka, N., Fujimoto, N., Takaka, T. and Shimo-oka, T. 2002, Biochem. Biophys. Res. Commun., 294, 1047.

22. Ritz-Timme, S., Laumeier, I. and Collins, M. J. 2003, Br. J. Dermatol., 149, 951.

23. Shapiro, S. D., Endicott, S. K., Province, M. A., Pierce, J. A. and Campbell, E. J. 1991, J. Clin. Invest., 87, 1828.

24. Kaneko, I., Yamada, N., Sakuraba, Y., Kamenosono, M. and Tutumi, S. 1995, J. Neurochem., 65, 2585.

25. Munegumi, T. and Shimoyama, A. 2003, Chirality, 15, S108.

26. Munegumi, T. 2010, Chemistry \& Biodiversity, 7, 1670.

27. Smith, G. G. and Reddy, G. V. 1989, J. Org. Chem., 54, 4529.

28. Liardon, R. and Hurrell, R. F. 1983, J. Agric. Food Chem., 31, 432.

29. Fujii, N., Muraoka, S., Satoh, K., Hori, H. and Harada, K. 1991, Biomed. Res., 12, 315.

30. Xie, M., Velde, D. V., Morton, M., Borchardt, R. T. and Schowen, R. L. 1996, J. Am. Chem. Soc., 118, 8955.

31. Radkiewicz, J. L., Zipse, H., Clarke, S. and Houk, K. N. 1996, J. Am. Chem. Soc., 118, 9148.

32. Catak, S., Monard, G., Aviyente, V. and Ruiz-Lopez, M. F. 2009, J. Phys. Chem. A, 113, 1111.
33. Bodor, H. and Huang, M. J. 1991, J. Comp. Chem., 12, 1182.

34. Kroeff, E. P. and Pietrzyk, D. J. 1978, Anal. Chem., 50, 502.

35. Kroeff, E. P. and Pietrzyk, D. J. 1978, Anal. Chem., 50, 1353.

36. Schwendinger, M. G. and Rode, B. M. 1992, Orig. Life, 22, 349.

37. Mitchell, A. R., Kent, S. B. H., Chu, I. C. and Merrifield, R. B. 1978, Anal. Chem., 50, 637.

38. Miyake, K. and Terada, H. 1978, J. Chromatogr., 157, 386.

39. Miyake, K., Mizuno, N. and Terada, H. 1986, Chem. Pharm. Bull., 34, 4787.

40. Albert, L., Hansch, C. and Elkins, D. 1971, Chem. Rev., 71, 525.

41. Carlson, R. M., Carlson, R. T. and Herbert, L. K. 1975, J. Chromatogr., 107, 219.

42. McCall, J. M. 1975, J. Med. Chem., 18, 549.

43. Mirrlees, M. S., Moulton, S. J., Murphy, C. T. and Taylor, P. J. 1976, J. Med. Chem., 19, 615.

44. Henry, D., Block, J. H., Anderson, J. L. and Carlson, G. R. 1976, J. Med. Chem., 19, 619.

45. Tanaka, N., Goodell, H. and Karger, B. L. 1978, J. Chromatogr., 158, 233.

46. Sangster, J. 1997, “Octanol-Water Partition Coefficients: Fundamentals and Physical Chemistry”, John Wiley \& Sons, New York.

47. LOGKOW Sangster Research Laboratories, http://logkow.cisti.nrc.ca/logkow/index.jsp

48. Lundanes, E. and Greibrokk, T. 1978, J. Chromatogr., 149, 241.

49. Benfenati, E., Gini, G., Piclin, N., Roncaglioni, A. and Vari, M. R. 2003, Chemosphere, 53, 1155.

50. Stewart, J. J. C. 2007, J. Mol. Model., 13, 1173.

51. Murakami, K., Irie, K., Morimoto, A., Ohigashi, H., Shindo, M., Nagao, M., Shimizu, T. and Shirasawa, T. 2003, J. Biol. Chem., 278, 46179.

52. Roher, A. E., Lowenson, J. D., Clarke, S., Wolkow, C., Wang, R., Cotter, R. J., Reardon, I. M., Zurcher-Neely, H. A., Heinrikson, R. L., Ball, M. J. and Greenberg, B. D. 1993, J. Biol. Chem., 268, 3072. 
53. Weinreb, P. H., Jarrett, J. T. and Lansbury Jr., P. T. 1994, J. Am. Chem. Soc., 116, 10835.

54. Raskatov, J. A. and Teplow, D. B. 2017, Scientific Reports, 7, 1.

55. Sugiki, T. and Utsunomiya-Tate, N. 2013, Biochem. Biophys. Res. Commun., 441, 493.
56. Sakai-Kato, K., Naito, M. and UtsunomiyaTate, N. 2007, Biochem. Biophys. Res. Commun., 364, 464.

57. Murakami, K., Uno, M., Masuda, Y., Shimizu, T., Shirasawa, T. and Irie, K. 2008, Biochem. Biophys. Res. Commun., 366, 745. 